\title{
ECOLOGICAL IMPACTS OF FIRE TRAILS ON PLANT ASSEMBLAGES IN EDGE HABITAT ADJACENT TO TRAILS
}

\author{
Daniel W. Krix, Matthew C. Hingee, Leigh J. Martin, Megan L. Phillips, \\ and Brad R. Murray*
}

School of Life Sciences, University of Technology Sydney, PO Box 123, Broadway, New South Wales 2007, Australia

"Corresponding author: Tel.: +61-2-9514-4075; e-mail: Brad.Murray@uts.edu.au

\begin{abstract}
Fire trails provide access into vegetation for controlled burns in fire-prone regions of the world. We examined the ecological impacts of fire trails on plant assemblages in edge habitat adjacent to trails in eucalypt woodlands of World Heritage Blue Mountains National Park, southeastern Australia. We found that understory plant species richness, total plant density, and leaf mass per area (LMA) were significantly higher in fire-trail edge habitat than in the understory of interior woodland habitat without fire trails. Understory plant species composition also differed significantly between fire-trail edge and interior habitats. Higher total plant density, higher LMA, and compositional differences in understory assemblages of fire-trail edge habitat were significantly related to increases in the availability of photosynthetically active radiation. In addition, higher soil clay content in fire-trail edges, which is linked to increased soil water availability for plant growth, was significantly related to higher species richness and compositional differences in the understory, as well as to compositional differences in overstory assemblages. From a conservation and management perspective, we suggest that, although

\section{RESUMEN}

Las sendas o "huellas" de fuego proveen de acceso a áreas vegetadas en distintos ecosistemas del mundo propensos al fuego. En este trabajo examinamos los impactos ecológicos de las huellas de fuego en el ensamble de plantas en bordes adyacentes a estas huellas, en bosques de eucaliptus del "Parque Nacional de las Montañas Azules" del sudeste de Australia, declarado como Patrimonio Histórico de la Humanidad. Encontramos que en el sotobosque de estos bordes, la riqueza de especies, la densidad total de plantas, y la masa de hojas por unidad de área (LMA), fueron significativamente mayores que en áreas del sotobosque interior sin presencia de estas huellas. La composición de especies también difirió entre ambos sotobosques (bordes de huellas e interior). La mayor densidad, masa de hojas por unidad de área (LMA) y diferencias en la composición de especies en los bordes de las huellas estuvieron significativamente relacionadas con incrementos en la disponibilidad de radiación fotosintéticamente activa. Adicionalmente, el mayor contenido de arcillas en los bordes de las huellas, el cual ha sido vinculado a incrementos en la disponibilidad de humedad para el crecimiento de las plantas, fue significativamente relacionado con una mayor riqueza y diferencias en la composición de especies del sotobosque, como así también en el ensamble de plantas del dosel superior. Desde la perspectiva de la conservación y el manejo,
\end{abstract}


significant ecological effects of fire trails on plant assemblages in edge habitats were detected, our work provides evidence that fire trails are unlikely to lead to serious conservation issues such as local extirpations of native species or the facilitation of exotic plant invasion. Nevertheless, our study has identified those plant species that are unique to, or particularly sparse or common in, fire-trail habitat, which should be prioritized for demographic and distributional monitoring should the need arise to increase the extent of fire trails in the future. sugerimos que aunque los efectos ecológicos de las huellas de fuego sobre los ensambles de plantas de sus bordes fueron significativos, nuestro trabajo provee evidencias de que es improbable que estas huellas de fuego conduzcan a serios problemas de conservación, como la extinción local de plantas nativas o la facilitación de invasión de plantas exóticas. No obstante, nuestro estudio ha identificado aquellas plantas que son únicas, particularmente dispersas, o comunes en hábitats de huellas de fuego, que deberían ser priorizadas para su monitoreo demográfico y distribucional, si fuese necesario incrementar la extensión de estas huellas de fuego en el futuro.

Keywords: controlled burn, plant functional traits, plant density, richness, species composition, trait-based ecology, woodlands

Citation: Krix, D.W., M.C. Hingee, L.J. Martin, M.L. Phillips, B.R. and Murray. 2017. Ecological impacts of fire trails on plant assemblages in edge habitat adjacent to trails. Fire Ecology 3(13): 95-119. doi: 10.4996/fireecology.130395119

\section{INTRODUCTION}

Globally, controlled burns are strategically used to manage threats posed by wildfires to life, property, and biodiversity (Gill 2001, Ellis et al. 2004, Penman et al. 2007, Bradstock et al. 2012, Spies et al. 2012, Price et al. 2015). Hazard reduction burns during cooler months of the year seek to reduce fuel loads before the commencement of the fire season, while back-burning operations create firebreaks that help slow the progress of wildfires. In fire-prone regions, fire trails (Figure 1a) are constructed to provide access into and throughout broad areas, such as national parks, for these fire management activities. With growing concern that wildfires will increase in frequency and intensity under future climate-change scenarios (Williams et al. 2001, Moriondo et al. 2006, Clarke 2013, Hughes and Steffen 2013), there is a need to maintain and possibly create more fire trails for management of fire risk. It is thus impera- tive that any ecological impacts of fire trails in wilderness areas are identified to ensure informed conservation of biodiversity and firerisk management.

Apart from the directly observable effects of clearing to remove vegetation for the creation of fire trails, there is currently a paucity of information about the ecological impacts of established fire trails on plant assemblages in edge habitats adjacent to trails. Previous work has shown that features like trails, such as sealed roads and walking paths that abut vegetation, bring about ecological changes to plant assemblages in edge habitats (Forman and Alexander 1998, Smit and Asner 2012, Neher et al. 2013, Ballantyne and Pickering 2015). Such changes include predominantly increases (but also decreases) in plant species richness and diversity (Angold 1997, Gelhausen et al. 2000, Watkins et al. 2003, Avon et al. 2010), changes in plant species composition compared to vegetation well away from the edge habitat (Karim and Mallik 2008), and increas- 

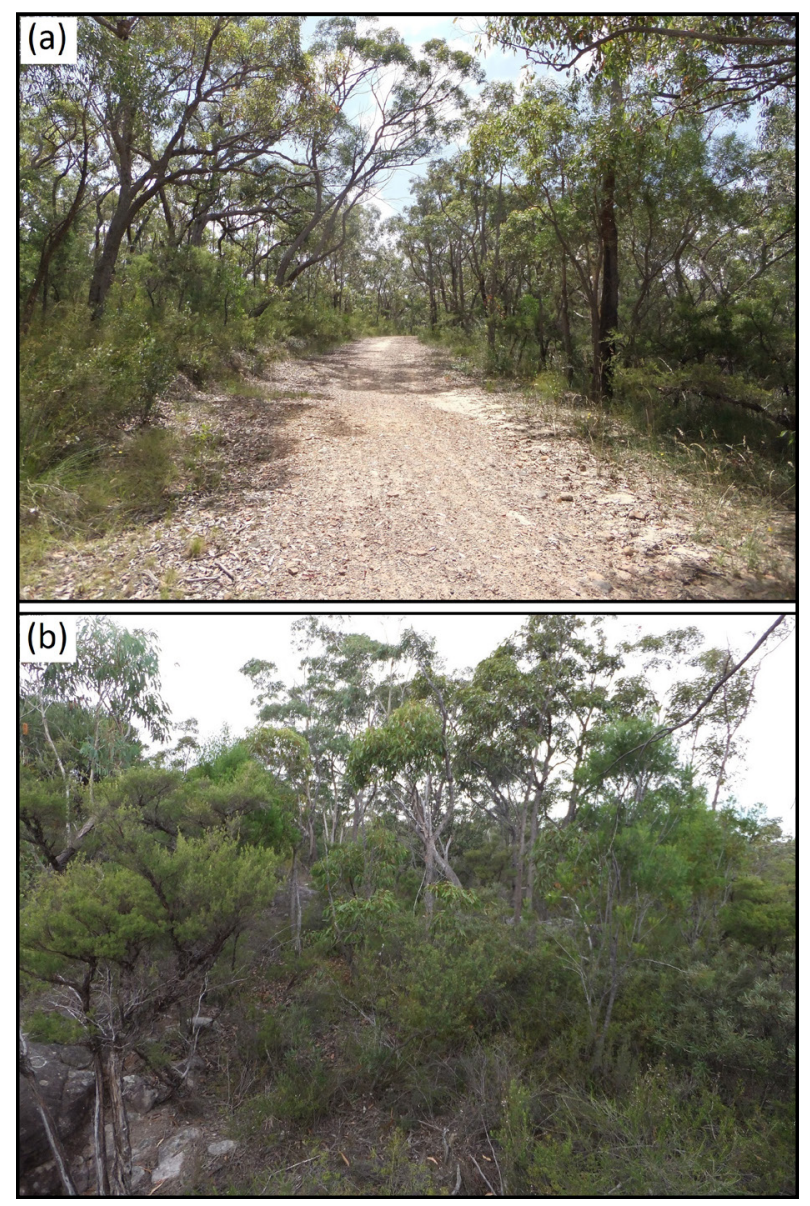

Figure 1. Examples of fire-trail (a) and interior (b) habitats in fire-prone woodland. Faulconbridge, NSW, Australia, 2014.

es in weed infiltration (Vakhlamova et al. 2016). A range of human activities have been linked to such alterations to plant assemblages, including motorized vehicles as a vector for the spread of weeds (Mortensen et al. 2009), pollution from vehicle emissions (Bignal et al. 2007), and the effects of high-traffic roads (Richard et al. 2000). Importantly, responses of plant assemblages in edge habitats are often underpinned by shifts in abiotic conditions in the edge habitat (Fox et al. 1997, Trombulak and Frissell 2000, Watkins et al. 2003, Pellisier et al. 2013). Plant assemblages directly adjacent to land cleared for access routes such as roads and paths are typically exposed to environmental conditions that differ from the interior of undisturbed vegetation (Matlack 1993).
For instance, removal of canopy cover can create brighter conditions at the interface between roads and forests compared with assemblages within forest interior (Delgado et al. 2007). The effects of an increased light environment have been well documented in these circumstances and include changes to both species richness and species composition of assemblages (Kupfer 1996, Gehlhausen et al. 2000, Avon et al. 2010, Vallet et al. 2010, Hofmeister et al. 2013, Suárez-Esteban et al. 2016). Additionally, erosion of road surfaces and deposition at road edges, as well as increased runoff, can increase available soil water in edge habitats, leading to increases in densities of species with a preference for moister environments (Avon et al. 2010; Wei et al. 2015, 2016).

In our study, we determined the ecological effects of established fire trails on plant assemblages in edge habitats adjacent to fire trails in woodlands in Blue Mountains National Park (BMNP). This region in southeastern Australia is one of the most fire-prone regions in the world (Hammill and Tasker 2010). With its large number of endemic species and high biodiversity value, it has been named a United Nations Educational, Scientific and Cultural Organization World Heritage Area (Hammill and Tasker 2010). As a fire-prone area of World Heritage significance, the BMNP provides insights into the ecological impacts of fire management activities that are potentially valuable in the management of fire-prone systems across the world. A key difference between our study and previous research on roads and other transport corridors is the low amount of vehicle traffic that fire trails receive, with fire trails often permanently closed to the public and used only during active fire fighting or hazard-reduction activities. This not only lowers vehicular damage to road surfaces and adjacent vegetation, but considerably reduces the impacts of vehicles as a vector of weed dispersal. Furthermore, during hazard-reduction burning, fires are initially set in vegetation 
alongside fire trails before being directed into the vegetation interior. Thus, the relative intensity of fire experienced in fire-trail edge habitats may be lower than that experienced in the interior of vegetation.

Based on previous findings for other types of edge habitats, we predicted that plant assemblages on the edges of fire trails (defined here as the area where vegetation begins on the side of the trail up to $2 \mathrm{~m}$ into woodlands immediately adjacent to the trail) would differ from assemblages not exposed to the influence of fire trails. We compared plant assemblage structure (species richness, total plant density), species composition, and functional traits (leaf mass per area, plant height, and seed mass) between edge habitat adjacent to fire trails (hereafter referred to as fire-trail habitat) and habitat in the interior of woodland vegetation well away from fire trails (referred to as interior habitat) to detect fire-trail impacts. We explored the effects of fire trails both at the level of the whole plant assemblage as well as the understory and overstory levels. We compared a range of environmental attributes related to light and soil environments shared between fire-trail and interior habitats to determine whether any observed differences in plant assemblages were linked to variation in environmental conditions. The findings from this research will be useful for land managers planning new trail construction, or wherever there is a need to understand potential impacts to vegetation by existing trails. For researchers, relationships emerging between measured functional traits and environmental attributes will contribute to trait-based ecology and provide a broadly applicable model of how this type of habitat disturbance might affect plant species based on their functional traits.

We addressed a series of predictions about the effects of fire trails on plant assemblages in edge habitats. Compared to interior habitat, in fire-trail habitat there should be:
(1) higher plant species richness and higher total plant density in response to the brighter conditions on edges (Avon et al. 2010, Suárez-Esteban et al. 2016);

(2) differences in species composition of assemblages concentrated in the understory, where changes to the light environment are greatest (Karim and Mallik 2008);

(3) higher leaf mass per area, which is a characteristic ecophysiological response of species to brighter conditions (Ackerly et al. 2002, Nardini et al. 2012);

(4) reduced plant height, as the need to invest resources in vertical growth to compete for light is lessened (Givnish 1982); and

(5) smaller seed mass as the smaller resources provided by lighter seeds (Moles and Westoby 2004) are offset by the greater available light for seedling growth, making smaller seeds more competitive.

\section{METHODS}

\section{Study Region}

The study was conducted in World Heritage BMNP (New South Wales, Australia), situated $60 \mathrm{~km}$ west of Sydney in southeastern Australia. The region experiences moderate temperatures throughout the year (mean annual temperature $=22^{\circ} \mathrm{C}$ ) with warm summers (mean $27^{\circ} \mathrm{C}$ ) and cool winters (mean $17^{\circ} \mathrm{C}$ ). Annual mean rainfall is $1090 \mathrm{~mm}$. The BMNP was selected for this study due to its ecological importance in the region and its fire-prone nature. The region supports 20 endangered plant species, eight endangered animal species, and eight endangered ecological communities (Blue Mountains City Council 2014). Wildfires occur at $10 \mathrm{yr}$ to $30 \mathrm{yr}$ intervals, with hazard-reduction activities ( $\geq 5 \mathrm{yr}$ intervals) usually restricted to slopes surrounding homes. To 
manage wildfire risk, fire trails have been constructed on ridgetops throughout the area to allow access for fire crews to perform prescribed burns. Fire trails throughout the region are typically unpaved, graded beds of compacted naturally occurring sand and exposed bedrock, with prohibitions on public vehicle, domestic animal, and agricultural animal access. Prescribed burns of sclerophyll woodlands on ridgetops can take place $7 \mathrm{yr}$ to $10 \mathrm{yr}$ since the vegetation was last burned (C. Brown, Rural Fire Service, Blaxland, New South Wales, Australia, personal communication). This situation provided for selection of study sites located in large areas of contiguous and otherwise undisturbed woodlands to examine the impacts of fire trails on native woodland plant assemblages in the region.

\section{Study Sites}

We established a total of 72 study sites across a $12 \mathrm{~km}^{2}$ region of Sydney Sandstone Complex Woodland in typical mid-mountains vegetation in two areas, Faulconbridge $\left(33^{\circ} 41^{\prime} \mathrm{S}, 150^{\circ} 32^{\prime} \mathrm{E}\right)$ and Linden $\left(33^{\circ} 42^{\prime} \mathrm{S}\right.$, $\left.150^{\circ} 29^{\prime} \mathrm{E}\right)$. In each area, we performed vegetation surveys at 36 sites. In both Faulconbridge and Linden, the 36 sites consisted of 18 sites in fire-trail habitat (Figure 1a) and 18 sites in interior habitat (Figure 1b). All 72 sites were $20 \mathrm{~m}$ long by $2 \mathrm{~m}$ wide (i.e., the dimensions of the sampling quadrat in which vegetation surveys were conducted; see the section on vegetation surveys below) and were located within vegetation that had not been burned for at least 10 years, which standardized all sites as established sclerophyllous woodland vegetation (sensu Murray et al. 1999). All sites were situated at least $200 \mathrm{~m}$ from any other site, public road, or built-up area, and lacked public mechanical vehicle access. We also avoided selecting sites that were near drainage ditches, composed of large areas of exposed rock, or on steep slopes without substantial vegetation. Fire-trail sites were se- lected where fire trails (mean width $=6 \mathrm{~m}$ ) had not been regraded within the last 10 years and where more than 20 years had passed since the construction of fire trails (Blue Mountains City Council 2014). Interior sites were situated on adjacent ridgetops without fire trails but of similar topographic position to ridges with fire trails. Sydney Sandstone Complex Woodland in the region is characterized by perennial eucalypt trees (e.g., Corymbia gummifera, Eucalyptus piperita), shrubs (e.g., Grevillea sericea, Dillwynia retorta, Acacia suaveolens, Hakea dactyloides) and herbs and grasses (e.g., Lomandra glauca, Entolasia stricta).

\section{Vegetation Surveys}

A $20 \mathrm{~m}$ long by $2 \mathrm{~m}$ wide sampling quadrat was placed at each site to record plant species richness, the density of each species (measured as number of individuals), total plant density (which provided a measure of plant productivity), and plant species composition. At fire-trail sites, the $20 \mathrm{~m}$ side ran parallel to the bearing of the fire trail along the ridgetop. The $2 \mathrm{~m}$ distance into vegetation, immediately adjacent to fire trails, was employed to capture impacts of fire trails on immediately adjacent plant assemblages as this is the leading-edge distance where any effects on plant species are typically greatest (Watkins et al. 2003, Avon et al. 2010). Quadrats at interior sites were similarly orientated lengthwise along the bearing of the ridge on which they were situated. All vascular plant species were identified using Robinson (2003) and Fairley and Moore (2010) as taxonomic sources. Species density was recorded as the count of discrete individuals (plant density). In total, 138 species (referring to both species and infra-species) were recorded across the habitats (Appendix 1). All species that we found were native to the region, with no exotic invasive or native invasive species recorded at any of the sites. 


\section{Plant Functional Traits}

We quantified leaf mass per area (LMA), plant height, and seed mass for each species. At all sites, we collected five leaves (one from each of five individuals) per species. If fewer than five individuals of a species were present at a site, some individuals provided more than one leaf to reach a maximum of five leaves. Healthy, fully developed leaves with a complete perimeter, still attached to sections of stem were detached from plants (Perez-Harguindeguy et al. 2013). Leaves were wrapped in wet tissue paper and placed in sealed plastic bags to minimize dehydration. Surface area of leaves was measured using ImageJ V1.48 (Schindelin et al. 2015). Leaves were then oven-dried at $80^{\circ} \mathrm{C}$ for $48 \mathrm{hr}$ and then weighed in groups of five leaves. The total weight of five leaves was divided by the summed surface area of the five leaves to determine LMA. Petioles were left attached to all leaves after removal from the stem at the natural abscission point for both scanning and weighing. Leaves of species arising from below ground level were cut at ground level. Ferns were processed by removing five individual (non-fertile) pinnae from the rachis. We used single-sided leaf area (two-dimensional cross-sectional area) as the projected area for species with terete leaves. Plant height measurements of five individuals of each species were recorded at each site by randomly selecting individuals from within the quadrat. If fewer than five individuals were encountered, all individuals of a species were measured for height. Height was measured to the nearest centimeter for plants up to a height of $5 \mathrm{~m}$ and a Haglöf EC II clinometer (Haglöf Sweden, Långsele, Västernorrland, Sweden) for plants more than $5 \mathrm{~m}$ in height. Data for seed mass for each species were collected from available sources including the Royal Botanic Gardens Kew (2014) and Murray (1997).

To determine assemblage-level values for each of the three functional traits at each site, we calculated community-weighted means (CWM). A CWM is a mean trait value across all species for a site, with each species' trait value weighted by the density of that species (Lavorel et al. 2008, Ricotta and Moretti 2011, Kleyer et al. 2012). The CWMs were calculated by applying the formula:

$$
C W M=\sum_{i=1}^{j} p_{i} x_{i}
$$

where $p_{\mathrm{i}}$ is the density of a species, and $x_{\mathrm{i}}$ the trait value for species $i$, calculated for $i$ to $j$ species (Ricotta and Moretti 2011).

\section{Environmental Attributes}

Photosynthetically active radiation. Fire trails are associated with reduced canopy cover and thus there is the potential for an increase in light availability for plants in fire-trail habitat. We measured both direct and diffuse transmitted photosynthetically active radiation (PAR) within the sampling quadrat at each site (referred to as above direct PAR and above diffuse PAR, respectively). We also measured direct and diffuse transmitted PAR within a quadrat on the fire trail itself (adjacent to each edge habitat survey quadrat) and within a woodland quadrat (adjacent to each interior survey quadrat) to capture the contrasting neighboring light conditions (referred to as neighbor direct PAR and neighbor diffuse PAR, respectively). This allowed us to determine any relative effects of light source (i.e., above or neighboring) on plant assemblages.

Hemispheric photographs were taken to quantify light conditions using a $4.5 \mathrm{~mm}$ F2.8 Ex Sigma circular fish eye lens (Sigma Corporation, Kawasaki, Kanagawa Prefecture, Japan) and Canon Eos 500D digital camera (Canon Inc., Ōta, Tokyo, Japan) mounted on a tripod. The lens was positioned approximately $1 \mathrm{~m}$ above ground level, pointed directly upward, with the top of the camera oriented to 
magnetic north. Photography was performed only on uniformly overcast days to ensure no overexposure of photos that would give false measures of canopy coverage during analysis. Three photographs were taken within each quadrat at $5 \mathrm{~m}, 10 \mathrm{~m}$, and $15 \mathrm{~m}$ as measured from the corner of the quadrat along the $20 \mathrm{~m}$ side and $1 \mathrm{~m}$ from the edge of the $2 \mathrm{~m}$ side. Gap Light Analyser (GLA) V2 (Cary Institute of Ecosystem Studies, Millbrook, New York, USA) was used to analyze the canopy photographs. This program determined direct and diffuse light at the point at which the image was taken (i.e., $1 \mathrm{~m}$ above ground). Data for total extra-terrestrial radiation and the monthly cloudiness index for the region (Australian Bureau of Meteorology 2014) were used to calculate the spectral fraction (the percentage of all solar radiation falling at ground level that is photosynthetically active) and the beam fraction (the percentage of direct and diffuse light as modified by clouds) as described in Frazer et al. (1999). These data, along with the mean elevation and the approximate center co-ordinate of all sites, were entered into the GLA program to calculate the incoming PAR at each site. The GLA software allows a user-defined setting of the color threshold when converting to black and white. For this reason, all images were converted into black and white within the program using the same threshold setting of 220 , chosen subjectively to best match the unmodified photographs, and used for all photographs for consistency between analyses.

Soil clay content. Soils of fire-trail and interior ridgetop sites were all sandy loams (Krix 2014). Sandy loam soils with higher clay content have higher water-holding capacity (Gupta and Larson 1979, Dexter 2004) and provide for increased water availability for plants (Kramer and Boyer 1995). We measured the percentage of soil clay content at each site to quantify comparative differences in soil water availability for plant growth. A $55 \mathrm{~mm}$ diameter circu- lar plastic tube was inserted into soils to a depth of $10 \mathrm{~cm}$ after clearing away leaf litter. Three soil sub-samples within each quadrat were collected. Soil samples were air dried for a minimum of three days. After passing through a $2 \mathrm{~mm}$ sieve, the sieved sub-samples for each site were bulked on an equal weight basis to form the samples used in subsequent analyses. Approximately $0.75 \mathrm{~g}$ of sample was sonicated in water for 5 minutes prior to analysis to break up conglomerated particles. A Malvern Mastersizer 2000 (Malvern Instruments, Malvern, Worcestershire, England, United Kingdom) was used to analyze the soil particles, with clay determined as the percentage of particles $<2 \mu \mathrm{m}$ for each sample. Mean percentage soil clay content for a site was determined from five separate measurements.

Soil nutrients. The three soil sub-samples described above were used to measure soil phosphorus (P) and soil potassium $(\mathrm{K})$ as representative soil nutrients; we did not include soil nitrogen as it is not a limiting nutrient in Australian soils (Lambers et al. 2008). Two sub-samples of $0.5 \mathrm{~g}$ from the sieved and bulked samples were digested in nitric acid $\left(\mathrm{HNO}_{3}\right)$ using a method adapted from Krishnamurty et al. (1976). Samples were placed in a beaker and $5 \mathrm{ml}$ of $70 \%$ analytical grade $\mathrm{HNO}_{3}$ added, then covered with a watch glass and allowed to reflux for several hours until the digest was complete. After digestion, 30\% hydrogen peroxide $\left(\mathrm{H}_{2} \mathrm{O}_{2}\right)$ was added to oxidize any remaining organic material. The sample was filtered into volumetric flasks and an aliquot drawn off for analysis via inductively coupled mass spectrometry. Results were adjusted for the initial weight of soil used in the digest and a mean for each quadrat was calculated.

\section{Statistical Analyses}

We compared environmental attributes (response variables in the form of continuous 
data) between fire-trail and interior habitats using separate general linear mixed models (univariate LMM, normal error structure, and identity link). We compared plant species richness and total plant density (response variables in the form of count data) between habitats using generalized linear mixed models (univariate GLMM, Poisson error structure, and $\log$ link). We included an observation-level random effect term in models to avoid over-dispersion in each GLMM (Bolker et al. 2009). Plant functional traits (leaf area, plant height, seed mass) were compared between fire-trail and interior habitats using univariate LMM (normal error structure and identity link), with seed mass requiring log-transformation prior to analysis. We fitted GLMM and LMM models using the Laplace approximation (Wolfinger 1993) and restricted maximum likelihood, respectively (with Satterthwaite approximation of degrees of freedom [Schaalje et al. 2002]). Habitat (fire trail, interior) was a fixed explanatory variable in models. Location (Faulconbridge, Linden) and a habitat $x$ location interaction term were random control variables included in models to account for variation between locations. For all non-permutational analyses, $P$ was set to alpha level of 0.05 .

We employed partial redundancy analysis (multivariate RDA), a constrained ordination technique using plant density data, to examine differences in plant species composition between the two habitats. A Hellinger transformation (Legendre and Legendre 2012) was applied before analysis and location was included as a conditioning term. Site was the level of replication in all analyses. The marginal significance of model terms was tested using a permutational ANOVA (9999 permutations).

We separately tested for habitat differences in the understory (defined as small shrubs, herbs, and grasses with foliage height $<1 \mathrm{~m}$ ) and the overstory (tall shrubs and trees with foliage height $\geq 1 \mathrm{~m}$ ) when a significant effect of habitat emerged across the whole plant as- semblage for species richness and plant density (GLMM), plant functional traits (LMM), and assemblage composition (RDA). This determined which stratum (or strata) generated significant habitat differences observed across the whole assemblage.

We built minimum adequate models (MAM) to relate those environmental attributes that differed significantly between habitats to each plant assemblage attribute (e.g., richness, composition) that also differed significantly between habitats (Crawley 2013). In each MAM, we first fitted a maximal model that included all environmental attributes and a habitat term (fire trail, interior) as explanatory variables. We tested the significance of each explanatory variable when removed from the maximal model. The variable with the lowest non-significant change in deviance was dropped and a reduced model was fitted with all remaining variables. This procedure was continued until a subset of explanatory variables was obtained, each producing a significant change in deviance when removed from a reduced model. If the habitat term was not retained in a MAM, then the other explanatory variables retained in that MAM captured the most important environmental differences between the two habitats for the univariate response variable (or species composition in the multivariate analysis). In contrast, if the habitat term was retained in a model, then variation in the response variable (or species composition) could be explained by other, unmeasured environmental attributes that differed between fire-trail and interior sites.

To distinguish differences in species composition between habitats with respect to species patterns, we first determined the number of species in common between the habitats. Second, we determined whether most species in assemblages were in significantly higher or lower density in fire-trail habitat compared with their density in interior habitat. To do this, we used paired sample $t$-tests that compared the total density of each species between 
fire-trail and interior habitats, with one test for the understory and one for the overstory. Third, we identified those species that were locally abundant or locally sparse in fire-trail habitat by calculating and plotting the total density of each species in fire-trail habitat against its total density in interior habitat. If a species had a density ratio $>2$ : 1 (i.e., twice as abundant in fire-trail compared with interior habitat), it was categorized as locally abundant. Species with a ratio $<1: 2$ (i.e., twice as abundant in interior compared with fire-trail habitat) were categorized as locally sparse. Finally, we identified unique species, which were those species occurring exclusively in either fire-trail or interior habitats. These relative attributions of locally abundant, sparse, and unique allowed us to identify which species were responding most notably to the presence of fire trails.

All univariate, multivariate, and graphical analyses were performed using $\mathrm{R}$ version 3.2.0 ( $\mathrm{R}$ Core Team 2015), with the packages beanplot (Kampstra 2008) for bean plot creation, lme4 (Bates et al. 2014) for LMM and GLMM modelling, lmerTest (Kuznetsova et al. 2014) for significance testing of LMM and GLMM models, TeachingDemos (Snow 2013) for general plotting functions and vegan (Oksanen et al. 2015) for RDA.

\section{RESULTS}

\section{Environmental Attributes}

We found that above direct PAR $\left(t_{1,70}=\right.$ 2.09, $P=0.04$; Figure 2a), neighbor direct $\operatorname{PAR}\left(t_{1,69}=6.18, P<0.001\right.$; Figure $\left.2 \mathrm{~b}\right)$, neighbor diffuse PAR $\left(t_{1,69}=6.35, P<0.001\right.$; Figure $2 \mathrm{c})$, and soil clay content $\left(t_{1,69}=2.62, P=0.03\right.$; Figure $2 d)$ were all significantly higher in firetrail habitat than in interior habitat. No significant differences were found for above diffuse $\operatorname{PAR}\left(t_{1,69}=0.94, P=0.35\right)$, soil $\mathrm{P}\left(t_{1,2}=-0.97\right.$, $P=0.43)$, or soil $\mathrm{K}\left(t_{1,2}=0.12, P=0.91\right)$.
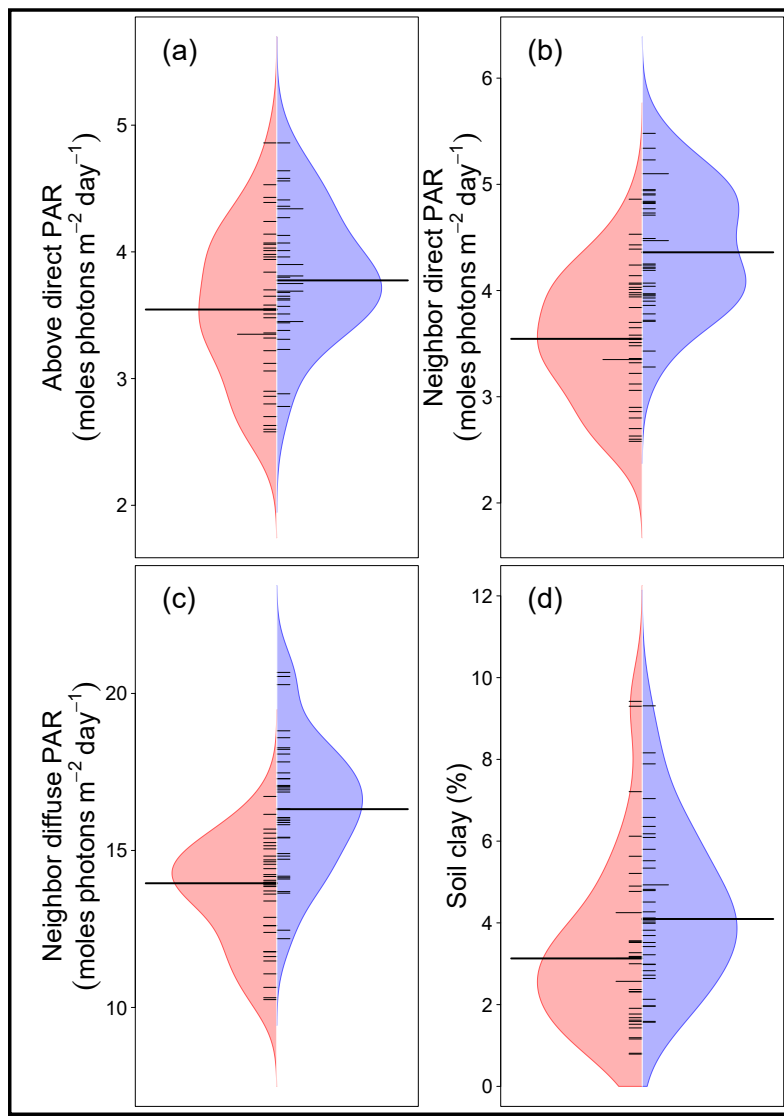

(d)

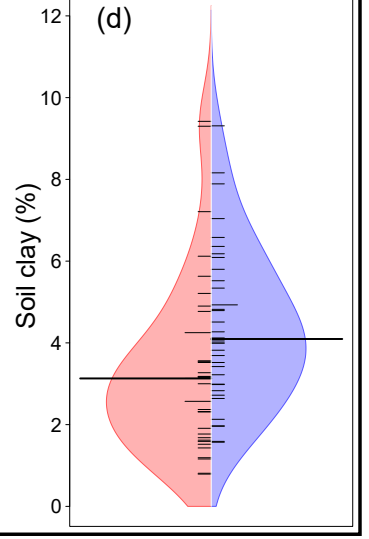

Figure 2. Beanplots of environmental attributes (a $=$ above direct PAR, $\mathrm{b}=$ neighbor direct PAR, $\mathrm{c}=$ neighbor diffuse PAR, $d=$ soil clay percentage) compared between interior (red) and fire-trail (blue) habitats. Estimated kernel densities with median values (thick black horizontal lines) and observations (thin black horizontal lines), with lengths proportional to number of observations). Horizontal width of the shaded area is proportional to the estimated density of the distribution at a given value of the attribute.

\section{Species Richness and Total Plant Density}

We found that plant species richness $\left(z_{1,67}\right.$ $=3.88, P<0.001$; Figure 3a) and total plant density $\left(z_{1,67}=2.20, P=0.03\right.$, Figure $\left.3 b\right)$ were significantly higher in fire-trail compared with interior habitat. These differences were generated by significantly higher richness $\left(z_{1,67}=\right.$ 4.21, $P<0.001$; Figure 3c) and plant density $\left(z_{1,67}=2.80, P=0.005\right.$; Figure $\left.3 \mathrm{~d}\right)$ in the understory, but not in the overstory (richness: $z=$ 


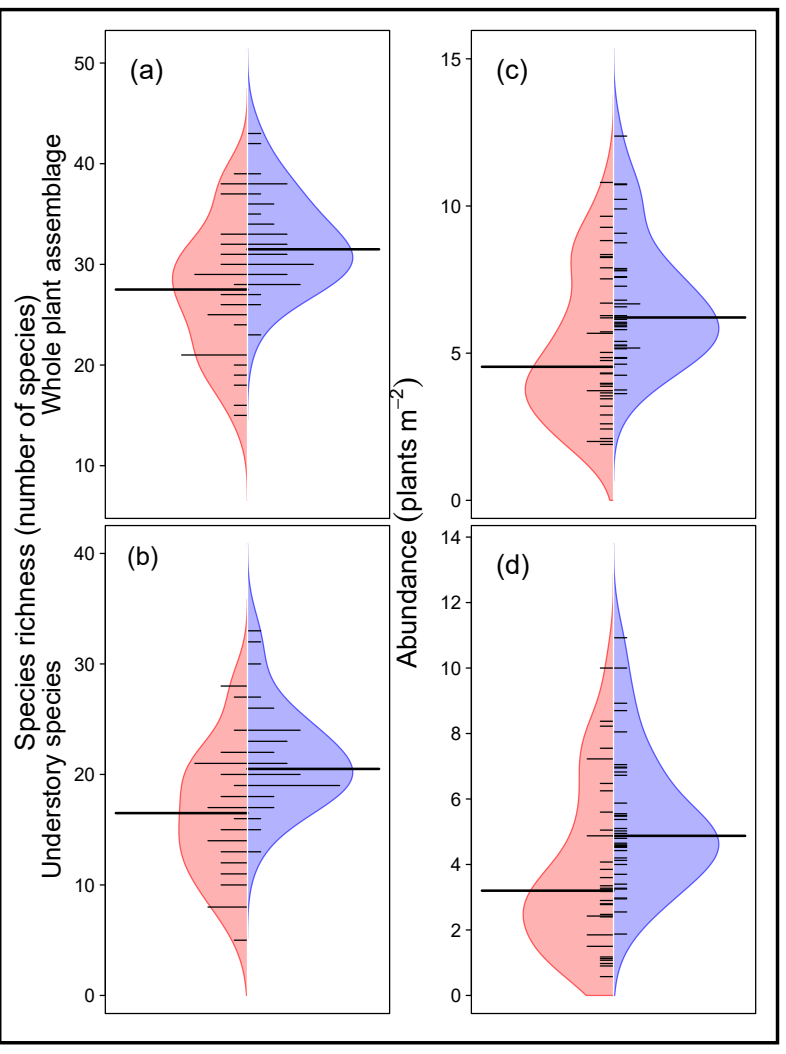

Figure 3. Beanplots of species richness (number of species) and plant abundance (plants $\mathrm{m}^{-2}$ ) compared between interior (red) and fire-trail (blue) habitats for the whole plant assemblage $(a, b)$ and understory (c, d). Estimated kernel densities with median values (thick lines) and observations (thin lines, lengths proportional to number of observations). Horizontal width of the shaded area is proportional to the estimated density of the distribution at a given value of the attribute.

$-0.15, P=0.88$; plant density: $z=-0.12, P=$ $0.91)$. We found that higher understory richness (estimate $=0.04 \pm 0.02 \mathrm{SE}, z_{2,66}=2.52, P$ $=0.01$ ) and plant density (estimate $=0.14 \pm$ $\left.0.03 \mathrm{SE}, z_{2,66}=5.02, P<0.001\right)$ were significantly related to higher soil clay content in fire-trail habitat. In addition, higher understory plant density was significantly related to higher neighbor diffuse PAR in fire-trail habitat (estimate $=0.10 \pm 0.03 \mathrm{SE}, z_{2,66}=3.51, P<0.001$ ). The MAM for understory richness retained the habitat term (estimate $=0.23 \pm 0.06 \mathrm{SE}, z_{2,66}=$ $3.59, P<0.001)$, demonstrating that other, unmeasured attributes of fire-trail habitat contrib- uted to higher understory richness. The habitat term was not retained in the MAM for understory plant density, with higher soil clay content and neighbor diffuse PAR capturing the most important environmental drivers of habitat differences in understory plant density.

\section{Plant Functional Traits}

We found no significant differences in CWM plant height $\left(t_{1,70}=-1.04, P=0.30\right)$ or CWM seed mass $\left(t_{1,70}=-0.98, P=0.51\right)$ between fire-trail and interior habitats. However, CWM LMA was significantly higher in firetrail habitat $\left(t_{1,70}=2.66, P=0.01\right.$; Figure $\left.4 \mathrm{a}\right)$, generated by higher CWM LMA in the understory $\left(t_{1,70}=2.93, P=0.005\right.$; Figure $\left.4 \mathrm{~b}\right)$, but not in the overstory $\left(t_{1,70}=-0.90, P=0.37\right)$. We found that understory CWM LMA was

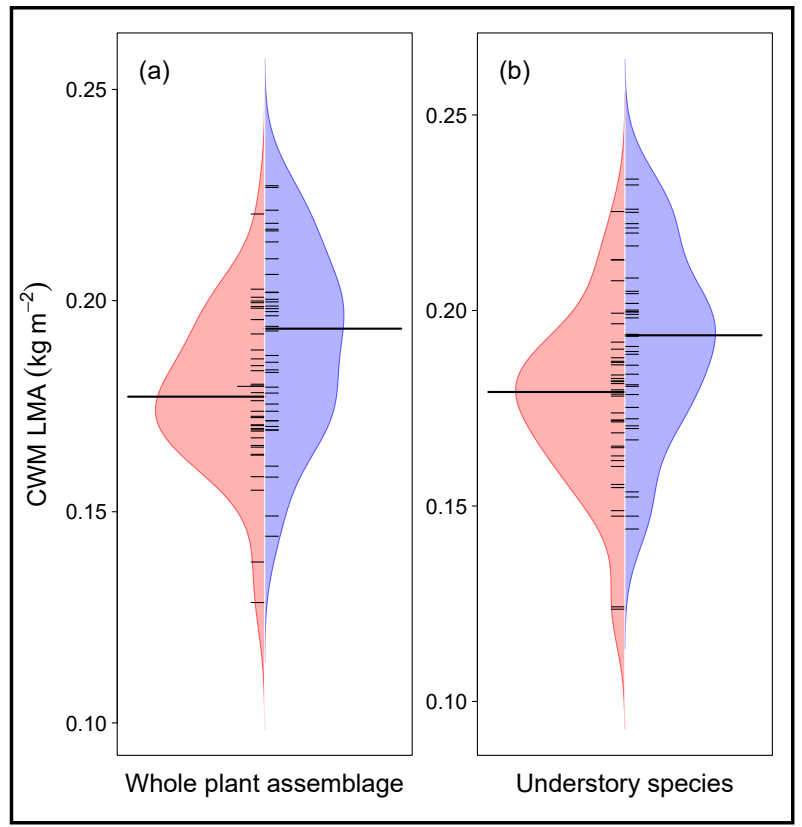

Figure 4. Beanplots of CWM LMA (leaf mass per area) compared between interior (red) and fire-trail (blue) habitats for the whole plant assemblage (a) and understory (b). Estimated kernel densities with median values (thick lines) and observations (thin lines, lengths proportional to number of observations). Horizontal width of the shaded area is proportional to the estimated density of the distribution at a given value of the attribute. 
significantly related to both soil clay content (estimate $=-0.004 \pm 0.001 \mathrm{SE}, t_{3,68}=-3.56, P$ $<0.001$ ) and above direct PAR (estimate $=$ $\left.0.01 \pm 0.005 \mathrm{SE}, t_{3,68}=2.22, P=0.03\right)$. The MAM for understory CWM LMA retained the habitat term (estimate $=0.02 \pm 0.005 \mathrm{SE}, t_{3,68}=$ $3.42, P=0.001)$, demonstrating that other, unmeasured attributes contributed to habitat differences in understory CWM LMA.

\section{Plant Species Composition}

Plant species composition differed significantly between fire-trail and interior habitats (RDA: $F_{1,69}=2.61, P<0.001$; Figure 5a), underpinned by significant compositional differences in both the understory (RDA: $F_{1,69}=$ 2.78, $P<0.001$; Figure 5b) and overstory (RDA: $F_{1,69}=1.79, P=0.03$; Figure 5c). Soil clay content $\left(\mathrm{RDA}\right.$ : variance $=0.03, F_{3,67}=$ 4.42, $P<0.001)$ and neighbor direct PAR (RDA: variance $=0.01, F_{3,67}=2.00, P=$ $0.007)$ were significantly related to variation in understory composition, while soil clay content (RDA: variance $=0.03, F_{1,69}=4.01, P$ $<0.001)$ was significantly related to variation in overstory composition. The MAM for understory composition retained the habitat term (RDA: variance $=0.01, F_{3,67}=2.17, P=$ 0.003 ), demonstrating that other, unmeasured attributes contributed to habitat differences in understory composition. The habitat term was not retained in the MAM for overstory composition, with variation in soil clay content emerging as the most important environmental driver of habitat differences in overstory composition.

\section{Species Driving Compositional Differences between Habitats}

Overall, a reasonably large number of species were found to be in common across habitats (109 of 139 species, $78 \%$ ), in both the understory (65 of 81 species, $80 \%$ ) and the overstory (44 of 58 species, $76 \%$ ). There were significantly higher plant densities within spe- cies in the understory of fire-trail habitat compared with their densities in interior habitat $\left(t_{80}\right.$ $=2.15, P=0.02)$, a pattern not repeated in the overstory $\left(t_{57}=1.49, P=0.07\right)$. We identified a number of plant species that were either comparatively locally abundant $(n=30)$ or locally sparse $(n=17)$ in fire-trail habitat for both the understory and the overstory (Figure 6, Table 1). Furthermore, 13 understory and four overstory species were found only in firetrail habitat, while three understory and nine overstory species were found only in interior habitat (Table 2). Comparing numbers of locally abundant and locally sparse species in fire-trail habitat (Figure 6, Table 1), there were approximately equal numbers of shrub species (locally abundant $n=15$, locally sparse $n=$ 12), tree species (both $n=2$ ), and graminoids (locally abundant $n=3$, locally sparse $n=1$ ). Forbs showed the strongest pattern with eight forb species recorded as locally abundant and no species recorded as locally sparse in firetrail habitat.

\section{DISCUSSION}

The findings of this study demonstrate that plant assemblages in edge habitat adjacent to fire trails differ from assemblages within similar woodland interior habitat that lack fire trails. We found that understory species richness, total plant density, and LMA were all significantly higher in fire-trail habitat compared with interior habitat. Furthermore, both understory and overstory species composition differed significantly between fire-trail and interior habitats. Observed increases in richness, density, and species composition were consistent with previous work in the area of edge ecology (e.g., Gelhausen et al. 2000, Avon et al. 2010). Given that most studies find significant weed infiltration in association with edge habitats that lead to increases in species richness (Suárez-Esteban et al. 2016), our results show that such increases at edges are possible among native plant species alone. We detected significant differences in PAR 

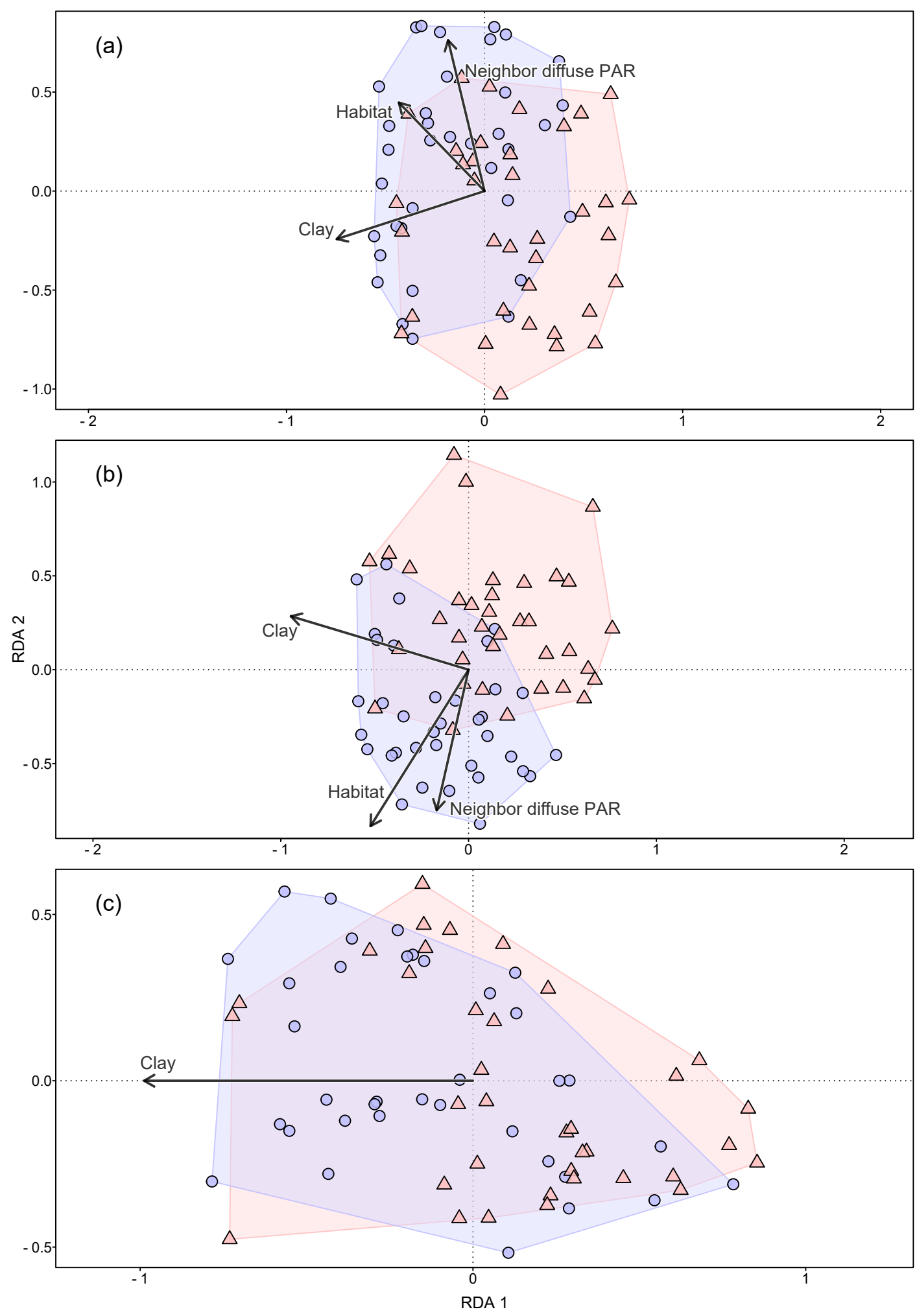

Figure 5. RDA biplots comparing species composition between fire-trail (blue) and interior (red) habitats for the whole plant assemblage (a), understory (b), and overstory (c). 


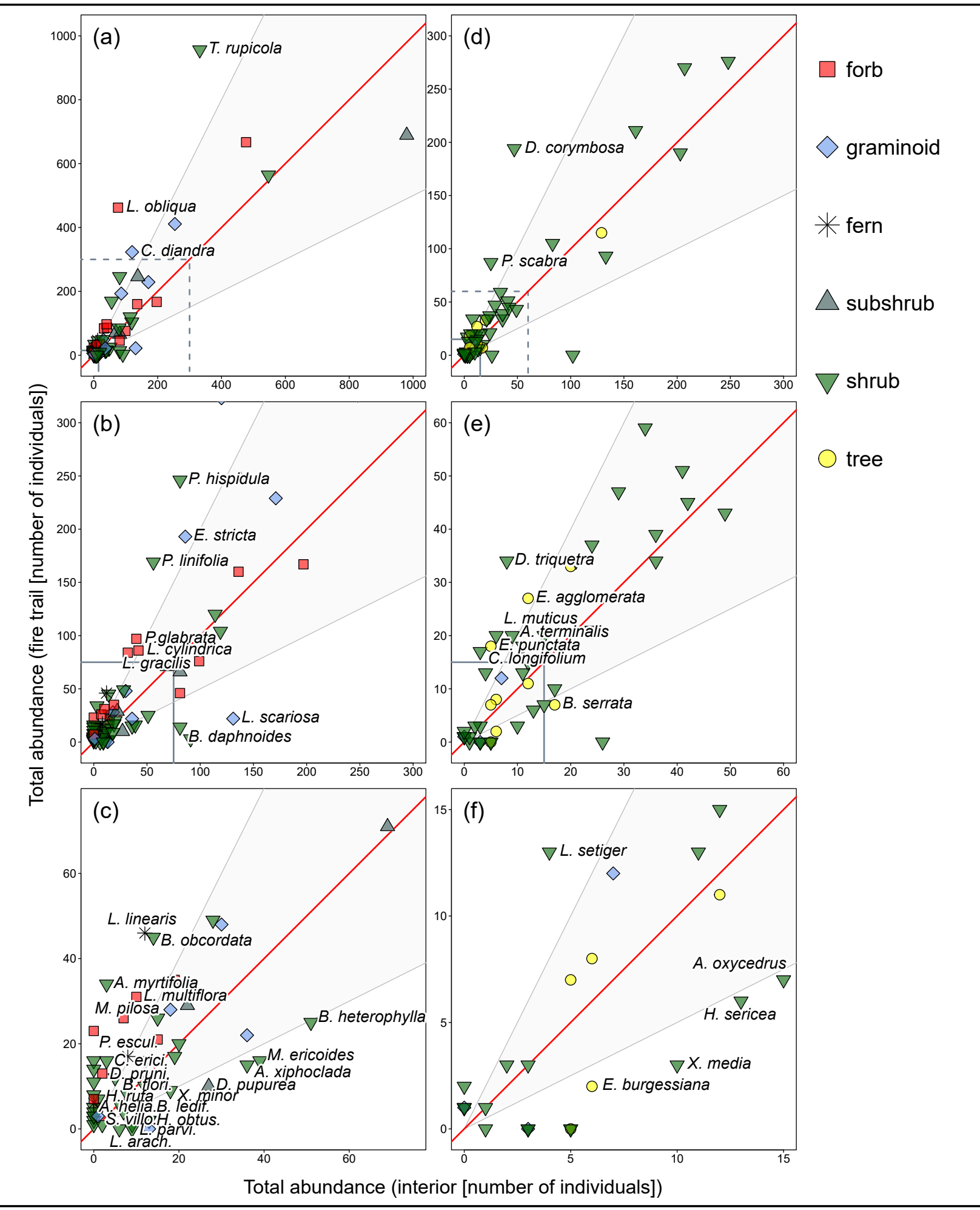

Figure 6. Total fire-trail density of species plotted against total interior density for understory $(a, b, c)$ and overstory $(\mathrm{d}, \mathrm{e}, \mathrm{f})$. Demarcated left corners of graphs are expanded for legibility. The 1:1 line representing equal density in both habitats is presented along with the 2:1 (above) and 1:2 (below) ratio lines. Species labeled above the 2:1 line are locally abundant, and below the 1:2 line are locally sparse, in fire-trail habitat (see Table 1). 
Table 1. Locally abundant and locally sparse species in fire-trail habitat. Density measured as total number of individuals in each habitat.

\begin{tabular}{|c|c|c|c|c|c|c|}
\hline \multirow{2}{*}{\multicolumn{3}{|c|}{\begin{tabular}{|c|}
$\begin{array}{c}\text { Functional } \\
\text { group }\end{array}$ \\
\end{tabular}}} & \multirow[b]{2}{*}{ Family } & \multirow[b]{2}{*}{ Species } & \multicolumn{2}{|c|}{ Density $(n)$} \\
\hline & & & & & Fire-trail & Interior \\
\hline \multirow{33}{*}{$=$} & & shrub & Fabaceae & Acacia myrtifolia & 34 & 3 \\
\hline & & forb & Apiaceae & Actinotus helianthi & 5 & 1 \\
\hline & & shrub & Rutaceae & Boronia floribunda & 12 & 5 \\
\hline & & shrub & Fabaceae & Bossiaea obcordata & 45 & 14 \\
\hline & & shrub & Polygalaceae & Comesperma ericinum & 16 & 3 \\
\hline & & graminoid & Cyperaceae & Cyathochaeta diandra & 323 & 120 \\
\hline & & forb & Phormiaceae & Dianella prunina & 13 & 2 \\
\hline & & graminoid & Poaceae & Entolasia stricta & 193 & 86 \\
\hline & $\mid$ & shrub & Dilleniaceae & Hibbertia rufa & 7 & 1 \\
\hline & $\Xi$ & forb & Anthericaceae & Laxmannia gracilis & 84 & 32 \\
\hline & $\frac{\hat{\sigma}}{\sigma}$ & fern & Lindsaeaceae & Lindsaea linearis & 46 & 12 \\
\hline & $\geqslant$ & forb & Lomandraceae & Lomandra cylindrical & 86 & 42 \\
\hline & $\mid$ & forb & Lomandraceae & Lomandra multiflora & 31 & 10 \\
\hline & 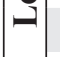 & forb & Lomandraceae & Lomandra obliqua & 462 & 76 \\
\hline & & forb & Loganiaceae & Mitrasacme pilosa & 26 & 7 \\
\hline & & forb & Iridaceae & Patersonia glabrata & 97 & 40 \\
\hline & & shrub & Rutaceae & Philotheca hispidula & 246 & 81 \\
\hline & & shrub & Thymelaeaceae & Pimelea linifolia ssp. linifolia & 169 & 56 \\
\hline & & fern & Dennstaedtiaceae & Pteridium esculentum & 17 & 8 \\
\hline & & graminoid & Cyperaceae & Schoenus villosus & 3 & 1 \\
\hline & & shrub & Elaeocarpaceae & Tetratheca rupicola & 956 & 332 \\
\hline & \multirow{12}{*}{ 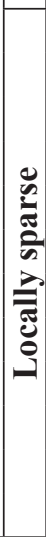 } & shrub & Euphorbiaceae & Amperea xiphoclada ssp. xiphoclada & 15 & 36 \\
\hline & & shrub & Rutaceae & Boronia ledifolia & 2 & 13 \\
\hline & & shrub & Fabaceae & Bossiaea heterophylla & 25 & 51 \\
\hline & & shrub & Ericaceae & Brachyloma daphnoides & 14 & 81 \\
\hline & & subshrub & Goodeniaceae & Dampiera purpurea & 10 & 27 \\
\hline & & shrub & Myrtaceae & Euryomyrtus ramosissima & 3 & 91 \\
\hline & & shrub & Dilleniaceae & Hibbertia obtusifolia & 2 & 13 \\
\hline & & shrub & Myrtaceae & Leptospermum arachnoides & 1 & 2 \\
\hline & & shrub & Myrtaceae & Leptospermum parvifolium & 1 & 9 \\
\hline & & graminoid & Restionaceae & Lepyrodia scariosa & 22 & 131 \\
\hline & & shrub & Picrodendraceae & Micrantheum ericoides & 16 & 39 \\
\hline & & shrub & Xanthorrhoeaceae & Xanthorrhoea minor & 9 & 18 \\
\hline \multirow{14}{*}{$\begin{array}{l}2 \\
0 \\
0 \\
0 \\
0 \\
0 \\
0 \\
0\end{array}$} & & shrub & Fabaceae & Acacia terminalis & 20 & 9 \\
\hline & & shrub & Proteaceae & Conospermum longifolium & 17 & 3 \\
\hline & 节 & shrub & Fabaceae & Daviesia corymbosa & 194 & 47 \\
\hline & E & shrub & Sapindaceae & Dodonaea triquetra & 34 & 8 \\
\hline & के & tree & Myrtaceae & Eucalyptus agglomerata & 27 & 12 \\
\hline & $\geqslant$ & tree & Myrtaceae & Eucalyptus punctata & 18 & 5 \\
\hline & : & shrub & Ericaceae & Leucopogon muticus & 20 & 6 \\
\hline & & shrub & Ericaceae & Leucopogon setiger & 13 & 4 \\
\hline & & shrub & Fabaceae & Pultenaea scabra & 87 & 25 \\
\hline & \begin{tabular}{|l|l|} 
\\
\end{tabular} & shrub & Fabaceae & Acacia oxycedrus & 7 & 15 \\
\hline & 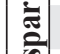 & tree & Proteaceae & Banksia serrata & 7 & 17 \\
\hline & $\begin{array}{ll}\infty \\
2 \\
2\end{array}$ & tree & Myrtaceae & Eucalyptus burgessiana & 2 & 6 \\
\hline & $\overline{\mathrm{E}}$ & shrub & Proteaceae & Hakea sericea & 6 & 13 \\
\hline & 焉 & shrub & Xanthorrhoeaceae & Xanthorrhoea media & 3 & 10 \\
\hline
\end{tabular}


Table 2. Unique species occurring exclusively in fire-trail or interior habitats. Total density is the total number of individuals across all sites in each habitat by stratum combination.

\begin{tabular}{|c|c|c|c|c|c|}
\hline & & $\begin{array}{c}\text { Functional } \\
\text { group }\end{array}$ & Family & Species & Total density \\
\hline \multirow{17}{*}{ 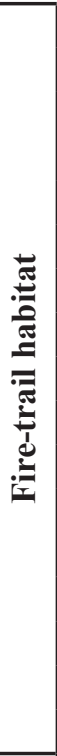 } & \multirow{13}{*}{ 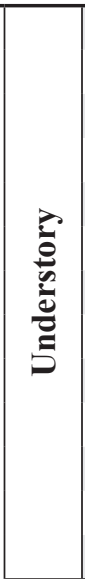 } & shrub & Fabaceae & Acacia gordonii & 3 \\
\hline & & shrub & Myrtaceae & Baeckea brevifolia & 2 \\
\hline & & shrub & Lamiaceae & Chloanthes stoechadis & 5 \\
\hline & & forb & Droseraceae & Drosera peltata & 23 \\
\hline & & shrub & Proteaceae & Grevillea mucronulata & 16 \\
\hline & & shrub & Myrtaceae & Harmogia densifolia & 1 \\
\hline & & shrub & Dilleniaceae & Hibbertia empetrifolia ssp. empetrifolia & 14 \\
\hline & & shrub & Dilleniaceae & Hibbertia riparia & 4 \\
\hline & & shrub & Malvaceae & Lasiopetalum ferrugineum var. cordatum & 8 \\
\hline & & fern & Lindsaeaceae & Lindsaea microphylla & 6 \\
\hline & & shrub & Rubiaceae & Pomax umbellata & 3 \\
\hline & & shrub & Phyllanthaceae & Poranthera corymbosa & 11 \\
\hline & & forb & Goodeniaceae & Scaevola ramosissima & 7 \\
\hline & \multirow{4}{*}{$\begin{array}{l}\vec{b} \\
0 \\
0 \\
0 \\
0 \\
0 \\
0\end{array}$} & shrub & Casuarinaceae & Allocasuarina distyla & 1 \\
\hline & & shrub & Ericaceae & Epacris microphylla var. microphylla & 1 \\
\hline & & shrub & Ericaceae & Leucopogon lanceolatus & 1 \\
\hline & & shrub & Proteaceae & Xylomelum pyriforme & 2 \\
\hline \multirow{12}{*}{ 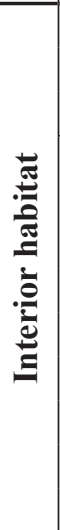 } & \multirow{3}{*}{ 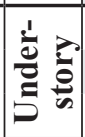 } & shrub & Rhamnaceae & Cryptandra amara & 6 \\
\hline & & graminoid & Cyperaceae & Lepidosperma concavum & 13 \\
\hline & & shrub & Rutaceae & Zieria laevigata & 9 \\
\hline & \multirow{9}{*}{$\begin{array}{l}\overrightarrow{0} \\
0 \\
0 \\
0 \\
0 \\
0\end{array}$} & shrub & Fabaceae & Acacia obtusifolia & 5 \\
\hline & & graminoid & Cyperaceae & Caustis pentandra & 3 \\
\hline & & tree & Myrtaceae & Corymbia eximia & 5 \\
\hline & & shrub & Myrtaceae & Eucalyptus sp. & 26 \\
\hline & & shrub & Myrtaceae & Leptopermum squarrosum & 1 \\
\hline & & shrub & Myrtaceae & Leptospermum polygalifolium & 3 \\
\hline & & shrub & Myrtaceae & Leptospermum sp. & 5 \\
\hline & & shrub & Ericaceae & Leucopogon esquamatus & 3 \\
\hline & & shrub & Ericaceae & Woollsia pungens & 102 \\
\hline
\end{tabular}

and soil clay content between fire-trail and interior habitats that were significantly related to the habitat differences that we observed in the plant assemblages.

High understory species richness and total plant density were significantly related to high soil clay content in fire-trail habitat. Increased clay content at the trail-vegetation interface is most likely a result of trail surface erosion and fine particle deposition (Akbarimehr and Naghdi 2012, Wade et al. 2012). We suggest that the increase in the availability of soil water for plants in fire-trail habitat, via increased clay content (Gupta and Larson 1979, Kramer and Boyer 1995, Dexter 2004), relaxes belowground competition for water as a limiting resource, thus permitting a higher richness of understory species to persist in higher density. Evidence for a link between soil water availability and plant density can also be seen in the moderate (but significant) negative relationship that we detected between CWM LMA and soil clay content, as comparatively lower LMA species tend to be more prevalent in moist environments at local scales (Ackerly et al. 2002). Interestingly, overstory species richness and density did not respond to increased soil water availability. The lack of re- 
sponse could be due to the localized nature of deposition of fine particles from fire trails in the upper region of the soil profile. This type of deposition would limit increases in soil water availability to smaller, shallower rooted species in the understory, relative to the deeper rooted overstory species. Larger, longer-lived species may also be slower to respond to the disturbance. In this context, any explanation for a lack of effect of increased soil water availability on overstory richness and density must account for the fact that soil clay content was a significant factor linked to compositional differences in overstory assemblages between the two habitats.

We found that high total plant density and compositional differences in understory assemblages were significantly related to high neighbor diffuse PAR in fire-trail habitat. This relationship emerged in part as a result of an increase in light availability lowering aboveground resource competition, with the brighter conditions in fire-trail habitat providing a means for understory species to achieve higher densities. The relationship between density and diffuse neighbor PAR is important here, because not only does diffuse PAR penetrate deeper into canopies than direct PAR (Urban et al. 2007), it also raises photosynthetic rates in leaves above those of direct PAR (Healey et al. 1998, Broderson et al. 2008). Interestingly, higher above direct PAR was significantly associated with higher CWM LMA. The shift to higher values of this functional trait in fire-trail habitat indicates that species with higher LMA are taking advantage of the brighter conditions, as their leaves are capable of greater photosynthetic rates in high light conditions (Poorter et al. 2009).

Plant assemblages in fire-trail and interior habitats were remarkably similar in composition, with a high percentage of species in common ( $78 \%$ for the whole assemblage). The significant difference that emerged in understory species composition between the two habitats was due to higher species richness and shifts to higher density in most species in fire-trail habitat. Further contributing to compositional differences in the understory and overstory were the species we identified as locally abundant and locally sparse in fire-trail habitat (Table 1), as well as the unique species in the two habitats (Table 2). Locally abundant and unique species in fire-trail habitat are particularly able to take advantage of increased light and water availability, as evidenced by the significant relationships that emerged between species composition and both soil clay content and neighbor direct PAR. Importantly, none of the locally abundant species or unique species in fire-trail habitat are recognized as "native weeds," so at this stage we suggest that their presence and increase in dominance is unlikely to lead to problems linked to overabundance as seen in other native species such as Pittosporum undulatum Vent. and Acacia baileyana F.Muell. Locally sparse species in fire-trail habitat and unique species in interior habitat appear less able to respond to the altered conditions associated with established fire trails. None of the locally sparse species or unique species in woodland interior, however, are listed as threatened, and it is unlikely that fire trails present a serious threat to the persistence of these species. Based on these patterns that we observed, we recommend that the locally abundant, locally sparse, and unique species identified in this study are those most deserving of monitoring should the need arise to construct more fire trails, increasing the overall area of fire-trail habitat throughout the woodlands.

Our approach of using minimum adequate models that included a habitat term enabled us to determine that there were attributes that we did not measure that contributed to higher species richness in the understory in fire-trail habitat, as well as to differences in understory species composition between fire-trail and interior habitats. These unmeasured attributes may include higher air and soil temperatures, or dif- 
ferences in vapor pressure deficit in fire-trail habitat (Matlack 1993, Gelhausen et al. 2000). We targeted two critical soil nutrients ( $\mathrm{P}$ and $\mathrm{K}$ ), and found that they neither differed significantly between the habitats nor contributed to between-habitat differences in plant assemblages. Indeed, we did not expect soil nutrients to differ between the two habitats, as it is unlikely that there is a mechanism by which fire trails expose vegetation at the trail interface to substantial increases or decreases in soil nutrient supply. Nevertheless, we included soil $\mathrm{P}$ and $\mathrm{K}$ as representative soil nutrients, given their importance for plant growth and because previous work has correlated variation in soil nutrients with vegetation gradients in woodland vegetation of eastern Australia (Le Brocque and Buckney 1994, King and Buckney 2002). The total lack of exotic plant species that we observed in fire-trail habitat is most likely because fire trails do not bring about substantial nutrient disturbance. In nutrient impoverished Australian soils, exotic plant species tend to occur where urban or agricultural runoff leads to considerable nutrient enrichment (Riley and Banks 1996, King and Buckney 2000).

We focused our study on vegetation immediately adjacent to fire trails, extending $2 \mathrm{~m}$ into woodland, to reveal a number of ecological effects of established fire trails. Previous work in the region has shown that edge effects associated with other disturbances including housing development, urban parks, and sealed roads can penetrate up to $60 \mathrm{~m}$ into woodland vegetation in the region (Anderson and Burgin 2002, Smith and Smith 2010). Fire trails are much less pronounced in terms of their intrusiveness when compared to these other disturbances, in that a much smaller amount of plant canopy cover is removed. While we would probably not expect edge effects of fire trails to extend as far as $60 \mathrm{~m}$, an important next step in quantifying fire-trail impacts will be to assess just how far the changes that we observed in plant assemblages extend from fire trails into woodland vegetation.

\section{CONCLUSION}

Our study has shown that established fire trails alter environmental conditions related to light and water availability for plants at trailvegetation interfaces. We determined that these environmental changes are correlated with shifts in species richness, plant density, plant functional traits, and the composition of plant assemblages when compared with assemblages within woodland interior that lack fire trails. Although we report significant ecological effects of fire trails on plant assemblages at trail-vegetation interfaces, close inspection of our findings suggest that these effects of fire trails, based on their current distribution and maintenance, are unlikely to cause problematic shifts in plant assemblages leading to conservation issues linked to local extirpations of plant species or management issues tied to the overabundance of native plant species. Further, our study recorded no evidence of the penetration of exotic plant species into any of the fire-trail sites, indicating that fire trails do not appear to be acting as conduits for the spread of exotic plants.

\section{ACKNOWLEDGEMENTS}

We thank C. Krix, G. Armstrong, C. Brown, R. Laren, and E. Ricketts for their support and advice on various aspects of this work. We are grateful to the editorial staff who handled the manuscript, and two anonymous referees for comments that helped to improve the manuscript. 


\section{LITERATURE CITED}

Ackerly, D.D., C.A. Knight, S.B. Weiss, K. Barton, and K.P. Starmer. 2002. Leaf size, specific leaf area and microhabitat distribution of chaparral woody plants: contrasting patterns in species level and community level analyses. Oecologia 130: 449-457. doi: 10.1007/ s004420100805

Akbarimehr, M., and R. Naghdi. 2012. Reducing erosion from forest roads and skid trails by management practices. Journal of Forest Science. 58: 165-169.

Anderson, L., and S. Burgin. 2002. Influence of woodland remnant edges on small skinks (Richmond, New South Wales). Austral Ecology 27: 630-637. doi: 10.1046/j.1442-9993.2002.01224.x

Angold, P.G. 1997. The impact of a road on adjacent heathland vegetation: effects on plant species composition. Journal of Applied Ecology 34: 409-417. doi: 10.2307/2404886

Australian Bureau of Meteorology. 2014. Climate Data Online. <http://www.bom.gov.au/climate/data/>. Accessed 6 September 2015.

Avon, C., L. Bergès, Y. Dumas, and J. Dupouey. 2010. Does the effect of forest roads extend a few meters or more into the adjacent forest? A study on understory plant diversity in managed oak stands. Forest Ecology and Management 259(8): 1546-1555. doi: 10.1016/j. foreco.2010.01.031

Ballantyne, M., and C.M. Pickering. 2015. The impacts of trail infrastructure on vegetation and soils: current literature and future directions. Journal of Environmental Management 164: 53-64. doi: 10.1016/j.jenvman.2015.08.032

Bates, D., M. Maechler, B. Bolker, and S. Walker. 2014. lme4: linear mixed-effects models using Eigen and S4. R package version 1.1-7. <http://CRAN.R-project.org/package=lme4>. Accessed 15 March 2015.

Blue Mountains City Council. 2014. Threatened species, Sydney. <http://www.bmcc.nsw.gov. $\mathrm{au} /$ sustainableliving/environmentalinformation/threatenedspecies $>$. Accessed 14 November 2014.

Bignal, K.L., M.R. Ashmore, A.D. Headley, K. Stewart, and K. Weigart. 2007. Ecological impacts of air pollution from road transport on local vegetation. Applied Geochemistry 22(6): 1265-1271 doi: 10.1016/j.apgeochem.2007.03.017

Bolker, B.M., M.E. Brooks, C.J. Clark, S.W. Geange, J.R. Poulsen, M.H.H. Stevens, and J.S. White. 2009. Generalized linear mixed models: a practical guide for ecology and evolution. Trends in Ecology and Evolution 24: 127-135. doi: 10.1016/j.tree.2008.10.008

Bradstock, R.A., G.J. Cary, I. Davies, D.B. Lindenmayer, O.F. Price, and R.J. Williams. 2012. Wildfires, fuel treatment and risk mitigation in Australian eucalypt forests: insights from landscape-scale simulation. Journal of Environmental Management 105: 66-75. doi: 10.1016/j. jenvman.2012.03.050

Brodersen, C.R., T.C. Vogelmann, W.E. Williams, and H.L. Gorton. 2008. A new paradigm in leaf-level photosynthesis: direct and diffuse lights are not equal. Plant, Cell and Environment 31: 159-164.

Clarke, H., C. Lucas, and P. Smith. 2013. Changes to Australian fire weather between 1973 and 2010. International Journal of Climatology 33(4): 931-944. doi: 10.1002/joc.3480

Crawley, M.J. 2009. The R Book. Second edition. John Wiley \& Sons Ltd, Chichester, West Sussex, England, United Kingdom. 
Delgado, J.D., N.L. Arroyo, J.R. Arévalo, and J.M. Fernández-Palacios. 2007. Edge effects of roads on temperature, light, canopy cover, and canopy height in laurel and pine forests (Tenerife, Canary Islands). Landscape and Urban Planning 81: 328-340. doi: 10.1016/j. landurbplan.2007.01.005

Dexter, A.R. 2004. Soil physical quality: part I. Theory, effects of soil texture, density, and organic matter, and effects on root growth. Geoderma 120: 201-214. doi: 10.1016/j.geoderma. 2003.09.004

Ellis, S., P. Kanowskin, and R. Whelan. 2004. National inquiry on bushfire mitigation and management council of Australian governments. Commonwealth of Australia, Canberra.

Fairley, A., and P. Moore. 2010. Native plants of the Sydney region. Third edition. Jacana Books, Sydney, Australia.

Forman, R.T.T., and L.E. Alexander. 1998. Roads and their major ecological effects. Annual Review of Ecology and Systematics 29: 207-231. doi: 10.1146/annurev.ecolsys.29.1.207

Fox, B.J., J.E. Taylor, M.D. Fox, and C. Williams. 1997. Vegetation changes across edges of rainforest remnants. Biological Conservation 82: 1-13. doi: 10.1016/S0006-3207(97)00011-6

Frazer, G.W., C.D. Canham, and K.P. Lertzman. 1999. Gap Light Analyzer (GLA), version 2.0. Imaging software to extract canopy structure and gap light transmission indices from true-color fisheye photographs. User's manual and program documentation. Simon Fraser University, Burnaby, British Columbia, Canada; and Cary Institute of Ecosystem Studies, Millbrook, New York, USA.

Gelhausen, S.M., M.W. Schwartz, and C.K. Augspurger. 2000. Vegetation and microclimatic edge effects in two mixed-mesophytic forest fragments. Plant Ecology 147: 21-35. doi: 10.1023/A:1009846507652

Gill, A.M. 2001. Economically destructive fires and biodiversity conservation: an Australian perspective. Conservation Biology 15: 1558-1560. doi: 10.1046/j.1523-1739.2001.01018.x

Givnish, T.J. 1982. On the adaptive significance of leaf height in forest herbs (Aster macrophyllus). American Naturalist 120(3): 353-381. doi: 10.1086/283995

Gupta, S.C., and W.E. Larson. 1979. Estimating soil water retention characteristics from particle size distribution, organic matter percent, and bulk density. Water Resources Research 15: $1633-1635$.

Hammill, K., and E. Tasker. 2010. Vegetation, fire and climate change in the Greater Blue Mountains World Heritage Area. Department of Environment, Climate Change and Water, Sydney, New South Wales, Australia.

Healey, K.D., K.G. Rickert, G.L. Hammer, and M.P. Bange. 1998. Radiation use efficiency increases when the diffuse component of incident radiation is enhanced under shade. Australian Journal of Agricultural Research 49: 665-672. doi: 10.1071/A97100

Hofmeister, J., J. Hošek, M. Brabec, R. Hédl, and M. Modrý. 2013. Strong influence of long-distance edge effect on herb-layer vegetation in forest fragments in an agricultural landscape. Perspectives in Plant Ecology, Evolution and Systematics 15: 293-303. doi: 10.1016/j. ppees.2013.08.004

Hughes, L., and W. Steffen. 2013. Be prepared: climate change and the Australian bushfire threat. Climate Council of Australian Ltd., Sydney, New South Wales, Australia.

Kampstra, P. 2008. Beanplot: a boxplot alternative for visual comparison of distributions. Journal of Statistical Software, Code Snippets 28: 1-9. <http:/www.jstatsoft.org/v28/c01/>. Accessed 15 March 2015. 
Karim, M.N., and A.U. Mallik. 2008. Roadside revegetation by native plants. I. Roadside microhabitat, floristic zonation and species traits. Ecological Engineering 232(3): 222-237. doi: 10.1016/j.ecoleng.2007.11.003

King, S.A., and R.T. Buckney. 2000. Urbanization and exotic plants in northern Sydney streams. Austral Ecology 25: 455-461. doi: 10.1046/j.1442-9993.2000.01085.x

King, S.A., and R.T. Buckney. 2002. Invasion of exotic plants in nutrient-enriched urban bushland. Austral Ecology 27: 573-583. doi: 10.1046/j.1442-9993.2002.01220.x

Kleyer, M., S. Dray, F. Bello, J. Lepš, R.J. Pakeman, B. Strauss, W. Thuiller, and S. Lavorel. 2012. Assessing species and community functional responses to environmental gradients: which multivariate methods? Journal of Vegetation Science 23: 805-821. doi: 10.1111/j.1654-1103.2012.01402.x

Kramer, P.J., and J.S. Boyer. 1995. Water relations of plants and soils. Academic Press, Inc., San Diego, California, USA.

Krishnamurty, K.V., E. Shpirt, and M.M. Reddy. 1976. Trace metal extraction of soils and sediments by nitric acid-hydrogen peroxide. Atomic Absorption Newsletter 15: 68-70.

Krix, D.W. 2014. Sun, seeds, leaves and height: the influences of fire trails on plant assemblies and their traits. Dissertation, University of Technology Sydney, Australia.

Kupfer, J. 1996. Patterns and determinants of edge vegetation of a Midwestern forest preserve. Physical Geography 17: 62-76.

Kuznetsova, A., P.B. Bruun Brockhoff, and R.H.B. Christensen. 2014. lmerTest: tests in linear mixed effects models. $\mathrm{R}$ package version 2.0-20. <https://CRAN.R-project.org/package $=$ lmerTest $>$. Accessed 15 March 2015.

Lambers, H., J.A. Raven, G.R. Shaver, and S.E. Smith. 2008. Plant nutrient-acquisition strategies change with soil age. Trends in Ecology and Evolution 23: 95-103. doi: 10.1016/j. tree.2007.10.008

Lavorel, S., K. Grigulis, S. McIntyre, N.S.G. Williams, D. Garden, J. Dorrough, S. Berman, F. Quétier, A. Thébault, and A. Bonis. 2008. Assessing functional diversity in the field-methodology matters! Functional Ecology 22: 134-147.

Le Brocque, A.F., and R.T. Buckney. 1994. Vegetation and environmental patterns on soils derived from Hawkesbury Sandstone and Narrabeen substrata in Ku-ring-gai Chase National Park, New South Wales. Australian Journal of Ecology 19: 229-238.

Legendre, P., and L. Legendre. 2012. Ecological resemblance. Developments in Environmental Modelling 24: 265-335. doi: 10.1016/B978-0-444-53868-0.50007-1

Matlack, G.R. 1993. Microenvironment variation within and among forest edge sites in the eastern United States. Biological Conservation 66: 185-194. doi: 10.1016/0006-3207(93)90004-K

Moles, A.T., and M. Westoby. 2004. Seedling survival and seed size: a synthesis of the literature. Journal of Ecology 92(3): 372-383. doi: 10.1111/j.0022-0477.2004.00884.x

Moriondo, M., P. Good, R. Durao, M. Bindi, C. Giannakopoulos, and J. Corte-Real. 2006. Potential impact of climate change on fire risk in the Mediterranean area. Climate Research 31: 85-95. doi: 10.3354/cr031085

Mortensen, D.A., E.S.J. Rauschert, A.N. Nord, and B.P. Jones. 2009. Forest roads facilitate the spread of invasive plants. Invasive Plant Science and Management 2(3): 191-199. doi: 10.1614/IPSM-08-125.1

Murray, B.R. 1997. Species in the tail of dominance/diversity curves: local abundance as related to abundance throughout geographic ranges. Dissertation, Macquarie University, Sydney, Australia. 
Murray, B.R., B.L. Rice, D.A. Keith, P.J. Myerscough, J. Howell, A.G. Floyd, K. Mills, and M. Westoby. 1999. Species in the tail of rank-abundance curves. Ecology 80: 1806-1816.

Nardini, A., G. Pedà, and N.L. Rocca. 2012. Trade-offs between leaf hydraulic capacity and drought vulnerability: morpho-anatomical bases, carbon costs and ecological consequences. New Phytologist 196(3): 788-798. doi: 10.1111/j.1469-8137.2012.04294.x

Neher, D.A., D. Asmussen, and S.T. Lovell. 2013. Roads in Northern hardwood forests affect adjacent plant communities and soil chemistry in proportion to the maintained roadside area. Science of the Total Environment 449: 320-327. doi: 10.1016/j.scitotenv.2013.01.062

Oksanen, J., G.F. Blanchet, R. Kindt, P. Legendre, P.R. Minchin, R.B. O’Hara, G.L. Simpson, P. Solymos, M. Henry, H. Stevens, and H. Wagner. 2015. Vegan: community ecology package. $\mathrm{R}$ package version 2.3-0. <https:/CRAN.R-project.org/package=vegan $>$. Accessed 15 March 2015.

Pellissier, V., L. Bergès, T. Nedeltcheva, M. Schmitt, C. Avon, C. Cluzeau, and J. Dupouey. 2013. Understorey plant species show long-range spatial patterns in forest patches according to distance-to-edge. Journal of Vegetation Science 24: 9-24. doi: 10.1111/j.1654-1103.2012.01435.x

Penman, T.D., R.P. Kavanagh, D.L. Binns, and D.R. Melick. 2007. Patchiness of prescribed burns in dry sclerophyll eucalypt forests in south-eastern Australia. Forest Ecology and Management 252: 24-32. doi: 10.1016/j.foreco.2007.06.004

Perez-Harguindeguy, N., S. Díaz, E. Garnier, S. Lavorel, H. Poorter, P. Jaureguiberry, M.S. BretHarte, W.K. Cornwell, J.M. Craine, D.E. Gurvich, C. Urcelay, E.J. Veneklaas, P.B. Reich, L. Poorter, I.J. Wright, P. Ray, L. Enrico, J.G. Pausas, A.C. de Vos, N. Buchmann, G. Funes, F. Quétier, J.G. Hodgson, K. Thompson, H.D. Morgan, H. ter Steege, M.G.A van der Heijden, L. Sack, B. Blonder, P. Poschlod, M.V. Vaieretti, G. Conti, A.C. Staver, S Aquino, and J.H.C. Cornelissen. 2013. New handbook for standardised measurement of plant functional traits worldwide. Australian Journal of Botany 61: 167-234. doi: 10.1071/BT12225

Poorter, H., U. Niinemets, L. Poorter, I.J. Wright, and R. Villar. 2009. Causes and consequences of variation in leaf mass per area (LMA): a meta-analysis. New Phytologist 182: 565-588. doi: $10.1111 / \mathrm{j} .1469-8137.2009 .02830 . \mathrm{x}$

Price, O.F., T.D. Penman, R.A. Bradstock, M.M. Boer, and H. Clarke. 2015. Biogeographical variation in the potential effectiveness of prescribed fire in south-eastern Australia. Journal of Biogeography 42: 2234-2245. doi: 10.1111/jbi.12579

R Core Team. 2016. R: a language and environment for statistical computing. R Foundation for Statistical Computing, Vienna, Austria.

Richard, T., T. Forman, and R.D. Deblinger. 2000. The ecological road-effect zone of a Massachusetts (U.S.A.) suburban highway. Conservation Biology 14(1): 36-46.

Ricotta, C., and M. Moretti. 2011. CWM and Rao's quadratic diversity: a unified framework for functional ecology. Oecologia 167: 181-188. doi: 10.1007/s00442-011-1965-5

Riley, S.J., and R.G. Banks. 1996. The role of phosphorus and heavy metals in the spread of weeds in urban bushlands: an example from the Lane Cove Valley, NSW, Australia. Science of the Total Environment 182: 39-52. doi: 10.1016/0048-9697(95)05033-7

Robinson, L. 2003. Field guide to the native plants of Sydney. Kangaroo Press, Sydney, New South Wales, Australia.

Royal Botanic Gardens Kew. 2014. Seed information database (SID) version 7.1. <https://data. kew.org/sid/>. Accessed 15 March 2015.

Schaalje, G.B., J.B. McBride, and G.W. Fellingham. 2002. Adequacy of approximations to distributions of test statistics in complex mixed linear models. Journal of Agricultural, Biological, and Environmental Statistics 7(4): 512-524. doi: 10.1198/108571102726 
Schindelin, J., C.T. Rueden, M.C. Hiner, and K.W. Eliceiri. 2015. The ImageJ ecosystem: an open platform for biomedical image analysis. Molecular Reproduction and Development 82: 518-529. doi: 10.1002/mrd.22489

Smit, I.P.J, and G.P. Asner. 2012. Roads increase woody cover under varying geological, rainfall and fire regimes in African savanna. Journal of Arid Environments 80: 74-80. doi: 10.1016/j. jaridenv.2011.11.026

Smith, P., and J. Smith. 2010. Urban edge effects in the Blue Mountains, New South Wales: implications for design of buffers to protect significant habitats. Pacific Conservation Biology 16: 92-100. doi: 10.1071/PC100092

Snow, G. 2013. TeachingDemos: demonstrations for teaching and learning. R package version 2.9. $<$ https://CRAN.R-project.org/package=TeachingDemos $>$. Accessed 15 March 2015.

Spies, T.A., D.B. Lindenmayer, A.M. Gill, S.L. Stephens, and J.K. Agee. 2012. Challenges and a checklist for biodiversity conservation in fire-prone forests: perspectives from the Pacific Northwest of USA and southeastern Australia. Biological Conservation 145: 5-14. doi: 10.1016/j.biocon.2011.09.008

Suárez-Esteban, A., L. Fahrig, M. Delibes, and J.M. Fedriani. 2016. Can anthropogenic linear gaps increase plant abundance and diversity? Landscape Ecology 31(4): 721-729. doi: 10.1007/s10980-015-0329-7

Trombulak, S.C., and C.A. Frissell. 2000. Review of ecological effects of roads on terrestrial and aquatic communities. Conservation Biology 14: 18-30. doi: 10.1046/j. 1523-1739.2000.99084.x

Urban, O., D. Janouš, M. Acosta, R. Czerný, I. Markova, M. Navratil, M. Pavelka, R. Pokorný, M. Šprtová, R. Zhang, and V. Špunda. 2007. Ecophysiological controls over the net ecosystem exchange of mountain spruce stand. Comparison of the response in direct vs. diffuse solar radiation. Global Change Biology 13: 157-168. doi: 10.1111/j.1365-2486.2006.01265.x

Vakhlamova, T., H.P. Rusterholz, Y. Kanibolotskaya, and B. Baur. 2016. Effects of road type and urbanization on the diversity and abundance of alien species in roadside verges in western Siberia. Plant Ecology 217(3): 241-252. doi: 10.1007/s11258-016-0565-1

Vallet, J., V. Beaujouan, J. Pithon, F. Rozé, and H. Daniel. 2010. The effects of urban or rural landscape context and distance from the edge on native woodland plant communities. Biodiversity and Conservation 19: 3375-3392. doi: 10.1007/s10531-010-9901-2

Wade, C.R., M.C. Bolding, W.M. Aust, and W.A. Lakel. 2012. Comparison of five erosion control techniques for bladed skid trails in Virginia. Southern Journal of Applied Forestry 36: 191-197. doi: 10.5849/sjaf.11-014

Watkins, R.Z., J. Chen, J. Pickens, and K.D. Brosofske. 2003. Effects of forest roads on understory plants in a managed hardwood landscape. Conservation Biology 17: 411-419. doi: 10.1046/j.1523-1739.2003.01285.x

Wei, L., A. Villemey, F. Hulin, I. Bilger, D. Yann, R. Chevalier, F. Archaux, and F. Gosselin. 2015. Plant diversity on skid trails in oak high forests: a matter of disturbance, micro-environmental conditions or forest age? Forest Ecology and Management 338: 20-31. doi: 10.1016/j.foreco.2014.11.018

Wei, L., F. Hulin, R.F. Chevalier, F. Archaux, and F. Gosselin. 2016. Is plant diversity on tractor trails more influenced by disturbance than by soil characteristics? Forest Ecology and Management 379: 173-184. doi: 10.1016/j.foreco.2016.08.020

Williams, A.A.J., D.J. Karoly, and N. Tapper. 2001. The sensitivity of Australian fire danger to climate change. Climatic Change 49: 171-191. doi: 10.1023/A:1010706116176

Wolfinger, R. 1993. Laplace's approximation for nonlinear mixed models. Biometrika 80(4): 791-795. doi: 10.1093/biomet/80.4.791 
Appendix 1. All plant species and infra-species recorded across the 72 sites and their occurrence (number of occupied quadrats out of 36) within fire-trail and interior habitats.

\begin{tabular}{|c|c|c|c|c|}
\hline & Family & Species or infra-species & Fire-trail & Interior \\
\hline & Fabaceae & Acacia echinula (DC.) Pedley & 4 & 3 \\
\hline & Fabaceae & Acacia gordonii (Tindale) Pedley & 1 & 0 \\
\hline & Fabaceae & Acacia myrtifolia (Sm.) Willd. & 3 & 1 \\
\hline & Apiaceae & Actinotus helianthi Labill. & 2 & 1 \\
\hline & Apiaceae & Actinotus minor (Sm.) DC. & 10 & 10 \\
\hline & Euphorbiaceae & Amperea xiphoclada ssp. xiphoclada (Spreng.) Druce & 4 & 9 \\
\hline & Myrtaceae & Baeckea brevifolia (Rudge) DC. & 1 & 0 \\
\hline & Pittosporaceae & Billardiera scandens $\mathrm{Sm}$. & 10 & 6 \\
\hline & Rutaceae & Boronia floribunda Sieber ex Spreng. & 3 & 3 \\
\hline & Rutaceae & Boronia ledifolia (Vent.) J.Gay ex DC. & 2 & 4 \\
\hline & Fabaceae & Bossiaea ensata Sieber ex DC. & 22 & 18 \\
\hline & Fabaceae & Bossiaea heterophylla Vent. & 10 & 14 \\
\hline & Fabaceae & Bossiaea obcordata (Vent.) Druce & 4 & 1 \\
\hline & Ericaceae & Brachyloma daphnoides (Sm.) Benth. & 6 & 17 \\
\hline & Cyperaceae & Caustis flexuosa R.Br. & 34 & 32 \\
\hline & Lamiaceae & Chloanthes stoechadis R.Br. & 1 & 0 \\
\hline & Polygalaceae & Comesperma ericinum DC. & 1 & 1 \\
\hline & Rhamnaceae & Cryptandra amara $\mathrm{Sm}$ & 0 & 1 \\
\hline & Cyperaceae & Cyathochaeta diandra (R.Br.) Nees & 22 & 13 \\
\hline & Goodeniaceae & Dampiera purpurea $\mathrm{R} . \mathrm{Br}$. & 2 & 1 \\
\hline & Goodeniaceae & Dampiera stricta (Sm.) R.Br. & 25 & 22 \\
\hline & Phormiaceae & Dianella caerulea Sims & 2 & 2 \\
\hline$\Xi$ & Phormiaceae & Dianella prunina R.J.F.Hend. & 6 & 1 \\
\hline تِ & Droseraceae & Drosera peltate Thunb. & 3 & 0 \\
\hline E & Poaceae & Entolasia marginata (R.Br.) Hughes & 5 & 3 \\
\hline di & Poaceae & Entolasia stricta (R.Br.) Hughes & 16 & 12 \\
\hline$\overbrace{0}^{0}$ & Myrtaceae & Euryomyrtus ramosissima (A.Cunn.) Trudgen & 2 & 4 \\
\hline$\frac{\overline{0}}{2}$ & Haloragaceae & Gonocarpus teucrioides DC. & 9 & 4 \\
\hline$\underline{B}$ & Goodeniaceae & Goodenia bellidifolia Sm. & 8 & 9 \\
\hline & Goodeniaceae & Goodenia decurrens R.Br. & 10 & 8 \\
\hline & Proteaceae & Grevillea mucronulata R.Br. & 6 & 0 \\
\hline & Proteaceae & Grevillea sericea (Sm.) R.Br. & 3 & 9 \\
\hline & Myrtaceae & Harmogia densifolia (Sm.) Schauer & 1 & 0 \\
\hline & Dilleniaceae & Hibbertia aspera ssp. aspera DC. & 3 & 1 \\
\hline & Dilleniaceae & Hibbertia empetrifolia ssp. empetrifolia (DC.) Hoogland & 1 & 0 \\
\hline & Dilleniaceae & Hibbertia obtusifolia DC. & 1 & 6 \\
\hline & Dilleniaceae & Hibbertia riparia (R.Br. ex DC.) Hoogland & 1 & 0 \\
\hline & Dilleniaceae & Hibbertia rufa N.A.Wakef. & 3 & 1 \\
\hline & Dilleniaceae & Hibbertia serpyllifolia DC. & 8 & 4 \\
\hline & Fabaceae & Hovea linearis (Sm.) R.Br. & 18 & 21 \\
\hline & Malvaceae & Lasiopetalum ferrugineum var. cordatum Benth. & 2 & 0 \\
\hline & Anthericaceae & Laxmannia gracilis $\mathrm{R} . \mathrm{Br}$. & 13 & 4 \\
\hline & Cyperaceae & Lepidosperma concavum R.Br. & 0 & 1 \\
\hline & Cyperaceae & Lepidosperma laterale R.Br. & 7 & 4 \\
\hline & Myrtaceae & Leptospermum arachnoides Gaertn. & 1 & 1 \\
\hline & Myrtaceae & Leptospermum parvifolium $\mathrm{Sm}$. & 1 & 1 \\
\hline & Restionaceae & Lepyrodia scariosa R.Br. & 4 & 10 \\
\hline & Ericaceae & Leucopogon appressus R.Br. & 1 & 1 \\
\hline & Ericaceae & Leucopogon ericoides (Sm.) R.Br. & 5 & 6 \\
\hline & Ericaceae & Leucopogon microphyllus var. microphyllus (Cav.) R.Br. & 1 & 2 \\
\hline & Lindsaeaceae & Lindsaea linearis Sw. & 3 & 1 \\
\hline
\end{tabular}


Appendix 1, continued. All plant species and infra-species recorded across the 72 sites and their occurrence (number of occupied quadrats out of 36) within fire-trail and interior habitats.

\begin{tabular}{|c|c|c|c|c|}
\hline & Family & Species or infra-species & Fire-trail & Interior \\
\hline \multirow{30}{*}{ 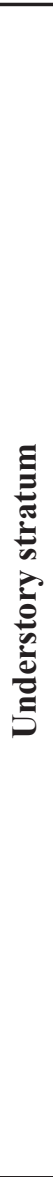 } & Lindsaeaceae & Lindsaea microphylla $\mathrm{Sw}$ & 1 & 0 \\
\hline & Lomandraceae & Lomandra cylindrica A.T.Lee & 11 & 5 \\
\hline & Lomandraceae & Lomandra glauca (R.Br.) Ewart & 33 & 27 \\
\hline & Lomandraceae & Lomandra longifolia Labill. & 5 & 5 \\
\hline & Lomandraceae & Lomandra multiflora (R.Br.) Britten & 11 & 5 \\
\hline & Lomandraceae & Lomandra obliqua (Thunb.) J.F.Macbr. & 25 & 10 \\
\hline & Proteaceae & Lomatia silaifolia (Sm.) R.Br. & 2 & 4 \\
\hline & Picodendraceae & Micrantheum ericoides Desf. & 2 & 2 \\
\hline & Fabaceae & Mirbelia rubiifolia (Andr.) G.Don & 15 & 8 \\
\hline & Loganiaceae & Mitrasacme pilosa Labill. & 4 & 4 \\
\hline & Ericaceae & Monotoca scoparia (Sm.) R.Br. & 14 & 14 \\
\hline & Malvaceae & Patersonia glabrata R.Br. & 13 & 7 \\
\hline & Malvaceae & Patersonia sericea $\mathrm{R} . \mathrm{Br}$. & 27 & 25 \\
\hline & Rutaceae & Philotheca hispidula (Spreng.) Paul G.Wilson & 29 & 20 \\
\hline & Phyllanthaceae & Phyllanthus hirtellus F.Muell. ex Müll.Arg. & 25 & 19 \\
\hline & Thymelaeaceae & Pimelea linifolia ssp. linifolia $\mathrm{Sm}$. & 31 & 23 \\
\hline & Apiaceae & Platysace linearifolia (Cav.) C.Norman & 36 & 36 \\
\hline & Poaceae & Poa sp. L. & 6 & 5 \\
\hline & Rubiaceae & Pomax umbellate (Geartn.) Sol. ex A.Rich. & 1 & 0 \\
\hline & Phyllanthaceae & Poranthera corymbose Brongn. & 3 & 0 \\
\hline & Pteridaceae & Pteridium esculentum (G.Forst.) Cockayne & 3 & 2 \\
\hline & Goodeniaceae & Scaevola ramosissima (Sm.) K.Krause & 5 & 0 \\
\hline & Cyperaceae & Schoenus imberbis R.Br. & 21 & 23 \\
\hline & Cyperaceae & Schoenus villosus R.Br. & 1 & 1 \\
\hline & Stylidiaceae & Stylidium graminifolium Sw. & 8 & 10 \\
\hline & Elaeocarpaceae & Tetratheca rupicola Joy Thomps. & 22 & 14 \\
\hline & Xanthorrhoeaceae & Xanthorrhoea minor R.Br. & 3 & 6 \\
\hline & Apiaceae & Xanthosia pilosa Rudge & 16 & 25 \\
\hline & Apiaceae & Xanthosia tridentata DC. & 10 & 6 \\
\hline & Rutaceae & Zieria laevigate Bonpl. & 0 & 3 \\
\hline \multirow{23}{*}{ 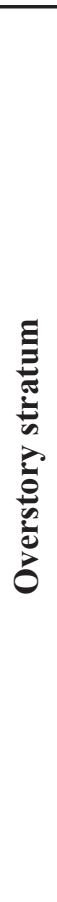 } & Fabaceae & Acacia brownii (Poir.) Steud. & 4 & 5 \\
\hline & Fabaceae & Acacia linifolia (Vent.) Wiild. & 6 & 3 \\
\hline & Fabaceae & Acacia obtusifolia A.Cunn. & 0 & 2 \\
\hline & Fabaceae & Acacia oxycedrus Seiber ex DC. & 3 & 7 \\
\hline & Fabaceae & Acacia suaveolens (Sm.) Wiild. & 17 & 13 \\
\hline & Fabaceae & Acacia terminalis (Salisb.) J.F.Macbr. & 7 & 6 \\
\hline & Fabaceae & Acacia ulicifolia (Salisb.) Court & 15 & 12 \\
\hline & Casuarinaceae & Allocasuarina distyle (Vent.) L.A.S.Johnson & 1 & 0 \\
\hline & Proteaceae & Banksia ericifolia L.f. & 2 & 1 \\
\hline & Proteaceae & Banksia serrata L.f. & 5 & 8 \\
\hline & Proteaceae & Banksia spinulosa $\mathrm{Sm}$. & 21 & 17 \\
\hline & Fabaceae & Bossiaea rhombifolia Seiber ex DC. & 22 & 19 \\
\hline & Cyperaceae & Caustis pentandra $\mathrm{R} . \mathrm{Br}$. & 0 & 2 \\
\hline & Cunoniaceae & Ceratopetalum gummiferum $\mathrm{Sm}$. & 3 & 2 \\
\hline & Proteaceae & Conospermum longifolium $\mathrm{Sm}$. & 4 & 1 \\
\hline & Myrtaceae & Corymbia eximia (Schauer) K.D.Hill \& L.A.S.Johnson & 0 & 1 \\
\hline & Myrtaceae & Corymbia gummifera (Gaertn.) K.D.Hill \& L.A.S.Johnson & 31 & 31 \\
\hline & Fabaceae & Daviesia corymbosa Sm. & 27 & 15 \\
\hline & Fabaceae & Dillwynia elegans Endl. & 22 & 10 \\
\hline & Fabaceae & Dillwynia retorta (J.C.Wendl.) Druce & 22 & 26 \\
\hline & Sapindaceae & Dodonaea triquetra J.C.Wendl. & 4 & 1 \\
\hline & Ericaceae & Epacris microphylla var. microphylla R.Br. & 1 & 0 \\
\hline & Ericaceae & Epacris pulchella Cav. & 13 & 12 \\
\hline
\end{tabular}


Appendix 1, continued. All plant species and infra-species recorded across the 72 sites and their occurrence (number of occupied quadrats out of 36) within fire-trail and interior habitats.

\begin{tabular}{|c|c|c|c|c|}
\hline & Family & Species or infra-species & Fire-trail & Interior \\
\hline \multirow{35}{*}{ 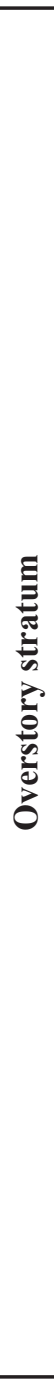 } & Myrtaceae & Eucalyptus agglomerate Maiden & 12 & 6 \\
\hline & Myrtaceae & Eucalyptus burgessiana L.A.S.Johnson \& Blaxell & 2 & 3 \\
\hline & Myrtaceae & Eucalyptus piperita $\mathrm{Sm}$. & 10 & 10 \\
\hline & Myrtaceae & Eucalyptus punctate DC. & 8 & 5 \\
\hline & Myrtaceae & Eucalyptus sp. L’Hér & 0 & 7 \\
\hline & Myrtaceae & Eucalyptus sparsifolia Blakely & 10 & 8 \\
\hline & Fabaceae & Gompholobium grandiflorum Sm. & 16 & 11 \\
\hline & Fabaceae & Gompholobium latifolium Sm. & 2 & 1 \\
\hline & Proteaceae & Grevillea phylicoides R.Br. & 16 & 12 \\
\hline & Proteaceae & Hakea dactyloides (Geartn.) Cav. & 16 & 11 \\
\hline & Proteaceae & Hakea laevipes Gand. & 7 & 7 \\
\hline & Proteaceae & Hakea sericea Schrad. \& J.C.Wendl. & 5 & 4 \\
\hline & Dilleniaceae & Hibbertia bracteata (R.Br. ex DC.) Benth. & 4 & 2 \\
\hline & Proteaceae & Isopogon anemonifolius (Salisb.) Knight & 13 & 13 \\
\hline & Proteaceae & Lambertia formosa $\mathrm{Sm}$. & 16 & 15 \\
\hline & Malvaceae & Lasiopetalum ferrugineum var. ferrugineum $\mathrm{Sm}$. & 4 & 2 \\
\hline & Cyperaceae & Lepidosperma filiforme Labill. & 3 & 2 \\
\hline & Cyperaceae & Lepidosperma viscidum R.Br. & 1 & 0 \\
\hline & Myrtaceae & Leptospermum polygalifolium Salisb. & 0 & 1 \\
\hline & Myrtaceae & Leptospermum sp. J.R. Forst. \& G. Forst. & 0 & 1 \\
\hline & Myrtaceae & Leptospermum squarrosum Geartn. & 0 & 1 \\
\hline & Myrtaceae & Leptospermum trinervium (Sm.) Joy Thomps. & 32 & 34 \\
\hline & Ericaceae & Leucopogon esquamatus R.Br. & 0 & 1 \\
\hline & Ericaceae & Leucopogon lanceolatus R.Br. & 1 & 0 \\
\hline & Ericaceae & Leucopogon muticus R.Br. & 3 & 5 \\
\hline & Ericaceae & Leucopogon setiger R.Br. & 5 & 2 \\
\hline & Proteaceae & Persoonia levis (Cav.) Domin & 7 & 7 \\
\hline & Proteaceae & Petrophile pulchella (Schrad. \& J.C.Wendl.) R.Br. & 19 & 18 \\
\hline & Fabaceae & Pultenaea scabra R.Br. & 9 & 2 \\
\hline & Fabaceae & Pultenaea tuberculata Pers. & 9 & 2 \\
\hline & Myrtaceae & Syncarpia glomulifera (Sm.) Nied. & 3 & 1 \\
\hline & Ericaceae & Woollsia pungens (Cav.) F.Muell. & 0 & 7 \\
\hline & Xanthorrhoeaceae & Xanthorrhoea arborea R.Br. & 1 & 1 \\
\hline & Xanthorrhoeaceae & Xanthorrhoea media R.Br. & 3 & 5 \\
\hline & Proteaceae & Xylomelum pyriforme (Geartn.) Knight & 2 & 0 \\
\hline
\end{tabular}

